\title{
Does religion matter for earnings management?
}

\author{
Eric O. Boahen* and Emmanuel C. Mamatzakis**
}

\section{October 2015}

\begin{abstract}
This paper explores the nexus between earnings management and religiosity. It complements prior research on the impact of religious social norms of the firm's environment on earnings management practices. Using a sample of 11,105 U.S. firm-year observations between 2004 and 2013, we find that religiosity is negatively associated with the accruals-based method, but positively related to both real-activities and classification shifting. This suggests that religiosity could serve as a correction mechanism to accruals earnings management practices. However, managers in highly religious areas consider real- activities and classification shifting as ethically and morally appropriate. In addition, we interact religiosity measures with governance variables to provide evidence of the importance of religion in relation to board characteristics. As part of robustness analysis we examine the impact of religion in high and low religious areas, as well as in urban and rural areas. Our findings remain robust and argue in favour of the importance of religious social norms in earnings management.
\end{abstract}

Keywords: Religiosity, Religious Social Norms, Earnings Management, Classification Shifting, and Corporate Governance.

JEL Classification: M41, M14, Z12

\footnotetext{
*Department of Business and Management, University of Sussex, Jubilee Building, Brighton, BN1 9SL, UK, e-mail: e.boahen@sussex.ac.uk. ** Department of Management and Economics, University of Sussex, Jubilee Building, Brighton, BN1 9SL, UK, e-mail: e.mamatzakis@ sussex.ac.uk.

Corresponding author: e.boahen@sussex.ac.uk (E. Boahen),
} 


\section{INTRODUCTION}

Research on earnings management has been rather prolific (Zalata and Roberts, 2015; Kim and Park, 2014; Donelson, Mcinnis \& Mergenthaler, 2013; Gao, 2013; Gerakos and Kovrijnykh, 2013, Wongsunwai, 2013, Boone, Khurana \& Raman, 2012; McGuire, Omer \& Sharp, 2012; Zang, 2012; Haw, Ho and Li, 2011), yet when it comes to studying the impact of religious social norm of the firms' environment no silver bullets have been offered (Dyreng, Mayew and Williams, 2010; Grullon, Kanatas, Weston, 2010). This paper provides a missing link in the literature as it provides a plethora of empirical evidence of the importance of religion for earnings management, whilst it sheds, for the first time, light of the impact of the former on classification shifting. ${ }^{1}$ Indeed, as religious social norms could influence the behaviour of managers (Dyreng et al., 2010; Grullon et al. 2010), it is reasonable to examine the impact of religious social norms on earnings management in a broader sense in order to help regulators, contract designers, accounting professionals, and even investors.

The existing few studies that have sought to establish an association between religious social norms of the firms' environment and earnings management practices have concentrated on accrual-based or real-activities based earnings management (McGuire et al. 2012, Callen, Morel and Richardson, 2011; Dyreng et al. 2010; Dechow, Sloan and Sweeney, 1996). However, none of these studies considered misclassification of core expenses into special items. Clearly, the effect of religion on classification shifting remains unexplored whilst findings from existing studies on the relationship between religiosity and earnings management are inadequate (McGuire et al., 2012; Hilary and Hui, 2009). As indicated by Sunder (2005), an understanding of religious social norms has tremendous effect on the shaping of appropriate financial standards and Levitt (1998) suggests that norms attrition underpins financial statement manipulation.

On another strand of the literature (Terpstra, Rozell and Robinson, 1993; Barnett, Jermier and Lafferty, 1996; Weaver and Agle, 2002; Conroy and Emerson, 2004; Longenecker,

\footnotetext{
${ }^{1}$ Classification shifting defines the deliberately misclassifying cost of goods sold, and the recording of general and administrative expenses as special items.
} 
McKinney and Moore, 2004) provides evidence of the impact of religiosity on business ethics. For example, Weaver and Agle (2002) observe that business ethics is positively related to religiosity especially when religion is an important part of individual's self-identity. Again, prior research indicates that highly religious individuals tend to hold conservative views and high moral standards than individuals with lower religious background (Terpstra et al. 1993; Barnett et al., 1996). Following these studies, Conroy and Emerson (2004) examine the association between religiosity and financial reporting and find that religiosity is negatively related to the use of accounting manipulation. Kennedy and Lawton (1998) observe that the higher the degree of religious social norms in an environment, the stronger its effect on people who live and operate in that environment. Similarly, Welch, Tittle and Petee (1991) note that the prominence attached to religious social norms in an environment has a great impact on individual's devotion to social norms, attitudes and beliefs. Thus managers' behaviour are shaped by the religious social norms of the population in the neighbourhood that surrounds them.

In addition, prior studies (Zalata and Roberts, 2015; Gonzalez and Garcia-Meca, 2014; Kim, Mauldin and Patro, 2014; Haw, Ho and Li, 2011; Lin and Hwang, 2010; Harris and Raviv, 2008) indicate that strong corporate governance acts as a form of monitoring mechanism, controls devious managerial behaviour and reduces information risk. Similarly, other studies also document that strong boards and audit committees mitigate earnings management practices. For example, (Xie, Davidson and DaDalt, 2003; Peasnell, Pope and Young, 2005) observe a negative association between board tenure, proportion of independent directors and accrual-based earnings management. Again, (Hossain, Mitra, Rezaee and Sarath, 2011) observe that the relationship between board size, number of meetings and accrual-based earnings management is negative. Also, audit committees (Abbott, Parker, Peters and Raghunandan, 2003), number of meetings and financial expertise (Coles, Daniel and Naveen, 2008), CEO tenure (Cadman and Sunder, 2014), number of outside directors (Chau and Gray, 2010) and CEO reputation (Francis, Huang, Rajgopal and Zang, 2008) have been found to affect earning management.

The objective of this paper is to complement and to comprehensively extend previous evidence of the impact of religious social norms on earnings management practices. In particular, we examine the association between religious social norms and accruals-based, 
real-activities based as well as on classification shifting earnings management in U.S. We also interact religiosity with corporate governance variables to assess the impact of religiosity and corporate governance on earnings management. We respond to the call by Callen et al., (2011) and McGuire et al., (2012) to examine the extent to which religion affects earnings management on a broader scale by exploring the association between religiosity and misclassification of expenses. Again, we focus on all U.S. states to establish the relationship between religiosity earnings management using all U.S. county level religious dataset from The Association of Religious Data Archives (ARDA) database and all US firms in the Compustat database. Overall, we identify 790 distinctive counties that are the headquarters of at least one of the firms on the Compustat annual database used in our analyses. We collect financial data from all firms on the Compustat database between 2004 and 2013.

From the analyses, we observe a significant association between religious social norms and the proxies for real- activities and classification shifting earnings management. On the other hand, in line with prior research (McGuire et al 2012; Callen et al, 2011) we find that religiosity is significantly related to the accrual-based earnings management. The results suggest that managers in a highly religious environment shun excessive forms of accrualbased earnings management despite the pressure to meet earnings targets but they are engaged in real-activities and misclassify core expenses into special items where there is limited or no external monitoring to meet capital market pressures. We conduct several analyses to examine the association between religiosity and our proxies for earnings management to support our results but our inferences remain the same.

In further analyses, we study the interaction between religiosity and corporate governance. Results show that religious social norms are significantly positively related to misclassification of expenses and real activities but negatively associated with accrual based earnings management when good corporate governance is observed. In such environments, religiosity serves as a form of monitoring for accrual based earnings management.

The paper makes three important contributions. First, we examine whether religiosity is associated with classification shifting, accruals-based and real-activities based earnings management. Second, we investigate whether firms in highly religious environment with good corporate governance affect managers from using real-activities and misclassification of 
core expenses into special items to meet earnings targets as a result of market pressures. Third, we show that for different measures and models, that take into account also corporate governance, religiosity is associated with accruals-based, real-activities-based and classification shifting earnings management respectively. In addition, the paper shows that religiosity impacts both firms in rural and urban areas, and that managers in religious environment favour classification shifting and real activities-based earnings management.

The rest of the paper is organised as follows. In section 2, we discuss the literature and develop the hypotheses. Section 3 covers research design, empirical methodology and estimation equations. Section 4 discusses data collection, sampling and descriptive statistics. The regression results are discussed in section 5. In addition, section 6 presents results of robustness tests and further sensitivity analyses. Section 7 provides conclusion and future research.

\section{HYPOTHESES DEVELOPMENT}

\subsection{Accrual-Based Earnings Management and Religious Social Norm}

From the view point of social norm theory, managers of firms operating in religious environment with diverse social norms exhibit varied behaviours (Tayler and Bloomfield, 2010). In fact, individuals' decisions are shaped by the moral values and social norms of the environment where they live or work. The resilience of religious social norms has posed great surprises in recent decades (Renneboog and Spaenjers, 2011; Hilary and Hui, 2009). For instance, prior research has established the relationship between religion and personal behaviour (Lehrer, 2004, p. 180), religion and development (Mersland, D'Espallier and Supphellen, 2012; Ter Haar \& Ellis, 2006), religion, economic attitudes and household income (Renneboog and Spaenjers, 2012). Indeed, establishing the link between individuals' religious values and economic development has been extensively covered in the economics literature but the link between religion and earnings management is scanty in the accounting literature (McGuire et al. (2012). Indeed, religious social norms are deemed to have influence on the behaviour of managers, it is therefore, reasonable to examine the impact of these religious norms on earnings management in order to help regulators, contract designers, accounting professionals, and even investors (Dyreng et al. 2010; Grullon et al. 2010). 
Accruals-based earnings management amount to generally accepted accounting principles (GAAP) violation, subject to external monitoring and auditors' scrutiny. Therefore, Bruns and Merchant (1990), indicate that accrual-based earnings management is fraudulent on ethical grounds. Again, Graham et al. (2005) note that it is risky and costly to depend on accruals earnings management because of the close scrutiny of external monitors and auditors. Despite the expectation to meet earnings targets and capital market pressures, prior research (McGuire et al., 2012; Callen et al, 2011; Dyreng et al., 2010; Hilary and Hui, 2009) observe that there is a negative relationship between the risk appetite levels of individuals and their religiosity. Again, Dyreng et al. (2010) and Grullon et al. (2010), report that firms in a highly religious environment report lower financial reporting irregularities. Similarly, McGuire et al. (2012) corroborated existing findings and indicate that firms headquartered in highly religious areas have lower accounting risk and misreporting associated with accounting restatements. Therefore, it could be that managers whose firms' are headquartered in a highly religious social norms environment will be less likely to be involved in accrualsbased earnings management. Following the above arguments and the perception that accrualbased earnings management is manipulative and unethical, the hypothesis that follows is that:

H1: Is accrual-based earnings management related to the religiosity of the firm's environment?

\subsection{Real-activities Earnings Management and Religious Social Norm}

Thus, previous researchers have indicated that religion affects individuals' behaviour and that religiosity enhances individual's ethical values and attitudes (Tayler and Bloomfield, 2010; Vitell, 2009; Parboteeah, Hoegl and Cullen, 2008). This view is also corroborated by Shu, Sulaeman and Yeung (2012) who find that individual's level of religiosity is positively correlated with high ethical values. According to Lehrer (2004), the personal religious values such as: discipline (Kennedy and Lawton, 1998), accountable (Iannaccone, 1998), honest (Keister, 2003) has the potential to influence the performance of firms and for that matter the characteristics of individuals. In a related study, Barro and McCleary (2003) assess the impact of religiosity on performance and observe that managers can maintain high levels of 
success and performance irrespective of the demographic and cultural background in which the moral values are implemented. Sunder (2005) underscores the importance of religious values to the stakeholders of the firm and find that the absence of religiosity can potentially harm stakeholders and affect the whole system and performance of the organisation (Omer, Sharp and Wang, 2010). In relation to earnings management, Merchant (1990) and Graham et al. (2005) observe that managers prefer real-activities to accruals-based earnings management because over reliance on accruals is costly, risky and subject to the scrutiny of auditors and regulators. Again, Gunny (2010) find that real activities earnings management influences the performance of the firm but Horton, Serafeim and Serafeim (2013) indicate that financial reporting process and quality can be distorted.

Conceptually, managers with strong religious values would be less inclined to engage in earnings management practices because of their strong morals, values, beliefs and attitudes. However, McGuire et al. (2012) observe that religious adherence does not exclude individuals from engaging in dishonest practices but Hillary and Hui (2009) find that firms headquartered in a highly religious social norms environment exhibits conventional corporate investing behaviour. Surprisingly, Callen et al., (2011) observe in a cross-country study that religion does not mitigate earnings management practices. A positive association between religious social norms of the firm's environment and real-activities based earnings management could exist because the latter does not involve GAAP violation, not subject to external monitoring and scrutiny of auditors. Therefore, it could be that religious managers would be involved in real-activities earnings management because there is no external monitoring or auditor vigilance on real- activities. Following the above and the desire to meet earnings targets due to capital market pressures, we posit that managers working in a highly religious social norms environment would be inclined to engage in real-activities earnings management to boost reported earnings. The following hypothesis is therefore presented to be tested:

H2: Is real-activities earnings management associated with the religiosity of the firm's environment? 


\subsection{Classification Shifting Earnings Management and Religious Social Norm}

In fact, previous studies to establish the association between religion and earnings management (McGuire et al., 2012; Callen et al., 2011; Dyreng et al, 2009) have ignored classification shifting as an earnings management method. Classification shifting re-arranges income statement items and does not change the bottom-line reported earnings and it involves; classifying operating expenses as discontinued operations (Barua et al., 2010), classifying operating expenses as extraordinary items (Ronen and Sadan, 1975; Barnea, 1976) and classifying operating expenses as special items (Fan et al., 2010; McVay, 2006). We investigate this gap in the earnings management literature. ${ }^{2}$ Zalata and Robert, (2015); Fan et al., (2010) and McVay, (2006) indicate that whilst the various methods of earnings management raise expectations of future performance, both real-activities and accrual-based earnings management have the effect of reducing future or past earnings. Consequently, the reputation and the quality of the company is compromised (Cao, Myers and Omer, 2012).

With classification shifting, McVay (2006) indicates that there is no change in reported earnings; rather core earnings are inflated as recurring items are shifted to non-recurring and exceptional items leading to a positive relationship between core earnings and special items (Behn, Gotti, Hermann and Kang, 2013). There is no implication for future reported earnings (Barua et al., 2010), therefore, external regulators pay less attention to classification shifting but subject other forms of earnings management to more scrutiny because of their potential effect to increase reported net income (Nelson et al., 2002). On ethical grounds, these studies (McGuire et al., 2012; Dryeng et al., 2010; Grullen et al., 2010) indicate that religiosity influences earnings management and curbs financial reporting irregularities (Hui, 2009). For example, Callen et al., (2011) find no relationship between religious social norms of the firms' environment and earnings management. However, McGuire et al., (2012) and Dyreng et al., (2010) report a negative association between religiosity and accrual-based earnings management but positive relationship between real-activities based earnings management and

\footnotetext{
${ }^{2}$ Classification shifting does not involve GAAP violation; auditors and regulators do not scrutinize classification shifting as they do for accrual-based and real-activities earnings management (Fan et al., 2010; McVay, 2006).
} 
religiosity. Scott (1995) argues that earnings management can be beneficial by signalling managers' inside information to investors. From the discussions above, we posit that managers in areas with strong religious backgrounds would see classification shifting as an avenue to signal managers inside information, good business practice and best approach for increasing the bottom line profit because of lack of external monitors. The above arguments therefore lead to the following hypothesis:

H3: Is there a relationship between classification shifting earnings management and the religiosity of the firm's environment?

\section{DATA AND DESCRIPTIVE STATISTICS}

\subsection{Measuring Religiosity}

We utilise religious dataset published by Religious Congregations and Membership Study (RCMS) between 1990 and 2010 to measure the strength of religious social norms. We use these datasets to create our proxy for religiosity. The religiosity dataset is derived from Association of Statisticians of American Religious Bodies (ASARB). The results of these surveys are published on the website of Association of Religion Data Archive (ARDA). The survey consists of an average of 173 religious bodies $^{3}$ and a total of 248,957 congregations with an average of $150,686,156$ adherents. This represents $51.9 \%$ of the average U.S. population during the period between 1990 and 2010. The average percentage of population showing religiosity and religious adherents from each U.S. County is $64.4 \%$ and respondents exceeded 55.9\% of the total population from each U.S. County. Religious adherents consist of all members, full members, communicants or non- communicants, baptized or nonbaptized, regular attendants, participants of weekly religious activities and those who consider religion as important part of their life.

Following prior studies (Dyreng et al., 2010; Grullon et al., 2009; Hilary and Hui, 2009) total religious adherents in each county for a period. The data are then scaled by the total county

\footnotetext{
3 Of this, there were on average 154 Christian denominations and associations (including Messianic Jews, Latter-Day Saints, and Universalist groups); there were also counts of Shinto, Sikh, Jain, National Spiritualist Association Congregations, and several congregations and adherents from three Buddhist groupings, four Hindu groupings, Baha's, four Jewish groupings, Zoroastrians and Muslims.
} 
population as reported by US Census Bureau of that same period. Conceptually, the higher the percentage of religious adherents in a county, the higher the impact of religious social norm on the firms headquartered in that county. Therefore, we use total number of religious adherents per capita in line with prior studies (Grullon et al., 2009; Hout and Greely, 1998). Overall, we identify 790 distinctive counties that are the headquarters of at least one of the firms on the Compustat annual database used in our analyses between 2004 and 2013. The county-level religiosity scores are matched to their respective U.S. States by merging them by year using the state code identifiers from the Compustat's company location code where firms are headquartered to derive the State-level religious dataset. We use religious dataset covering all U.S. States. The data requirement for each dependent and independent variable is a function of the number of observations and test required for the analysis.

Table 1 below provides descriptive statistics for the measure of RELIGIOSITY (REL). Table 1 shows that religiosity in the U.S. is declining from an average of approximately $60 \%$ in 1990 to an average of $48 \%$ in 2010 in each county. This is consistent with the 2008 American Religious Identification Survey, which reports a substantial decline in religiosity among US population between 1990 and 2008. In addition, Table 1 indicates that approximately 54\% of all people in each US are affiliated with a religion, attend a religious activity or considers religion as important in their life.

TABLE 1: Descriptive Statistics for Religiosity

\begin{tabular}{lccccccc}
\hline Variable & Mean & Std. Dev. & Q1 & Median & Q3 & Skewness & kurtosis \\
\hline REL & 53.5 & 18.07 & 36.27 & 52.47 & 63.33 & 0.83 & 2.69 \\
RELAdh -1990 & 59.5 & 20 & 44.8 & 59.5 & 73 & 0.87 & 2.4 \\
RELAdh -2000 & 53 & 18.6 & 39.4 & 51.1 & 64.7 & 0.74 & 2.98 \\
RELAdh -2010 & 48 & 15.6 & 24.6 & 46.8 & 52.3 & 0.88 & 2.68 \\
\hline
\end{tabular}

Notes: Religiosity (REL) = is the variable of interest, measured as the average of US counties religiosity score weighted by the county's population for the period, 19902000 and 2010. RELAdh = a measure of religious adherence for US counties in 1990, 2000 and 2010. Association of Statisticians of American Religious Bodies (ASARB) collects religiosity dataset, which are published by the Association of Religion Data Archive (ARDA).

In the robustness tests, we use Gallup religious database for the twenty most and least religious US States for the same study period. Based on the responses collected by Gallup, on 
whether religion is important, respondents attend religious activities weekly or are affiliated with religion, Mississippi came out, as the most religious state, whilst Vermont is the least religious state. The most religious states are mainly in the South, with the exception of Utah, while the least religious states are concentrated in New England and the West.

Table 2: Comparison of Most and Least Religious States in the US

\begin{tabular}{l|c|lc}
\hline \multicolumn{1}{c}{$\begin{array}{c}\text { Ten Most } \\
\text { Religious States in US }\end{array}$} & $\begin{array}{c}\text { Ranking } \\
\text { Top States }\end{array}$ & \multicolumn{1}{c}{$\begin{array}{c}\text { Ten Least } \\
\text { Religious States in US }\end{array}$} & $\begin{array}{c}\text { Ranking } \\
\text { Bottom States }\end{array}$ \\
\hline Mississippi & 1 & Vermont & 1 \\
Utah & 2 & New Hampshire & 2 \\
Alabama & 3 & Maine & 3 \\
Louisiana & 4 & Massachusetts & 4 \\
South Carolina & 5 & Oregon & 5 \\
Tennessee & 6 & Nevada & 6 \\
Georgia & 7 & Washington & 7 \\
Arkansas & 8 & Connecticut & 8 \\
North Carolina & 9 & Hawaii & 9 \\
Oklahoma & 10 & District of Columbia & 10 \\
\hline Notes: Table 2 shows comparison of most and least religious states in the US compiled by Gallup. Since 1965, Gallup has \\
conducted interviews about US adults religiosity. The results over the years suggest that religious attitudes are very stable, \\
consistent with ASARB studies. The percentage of US adults who consider religion to be important according to Gallup are \\
as follows: 1990 = 58 percent; 2000 = 58 percent; 2005 =55 percent; 2006 = 56 percent; 2007 = 56 percent; 2008 = 54 \\
percent; 2009 =56 percent; 2010 =56 percent.
\end{tabular}

\subsection{Control Variables}

In addition to the variable of interest, we include additional firm-level and county-level demographic control variables that prior research indicates are the determinants of earnings management. In particular, we control for the presence of BIG4 auditors ${ }^{4}$ (Barton, 2005), analyst following (Brochet, Miller and Srinivasan, 2013), profitability, audit tenure and growth opportunities because these factors impact on the choice of earnings management methods (McGuire et al. 2012; Cohen and Zarowin, 2010). For example, Becker et al. (1998) observe that there is a negative association between audit quality and earnings management. In addition, we control for firms located in rural areas because prior research (Walker, 2013; Urcan, 2007) observe that higher earnings quality is associated with firms located in rural areas. Again, using percentage change in gross domestic product as a proxy for changes in economic activities, we control for differences in economic activities between years as

${ }^{4}$ BIG4 auditors include - PricewaterHousecoopers (PwC), KPMG, Deloitte \& Touché, and Ernst \& Young. 
changes in economic conditions could impact on real activities of firms (McGuire et al. 2012; Cohen and Zarowin, 2010; Cohen et al. 2008). Given that there is a costs associated with earnings management, we include net operating assets of each firm to control for earnings management. Also, we control for return on assets because firm performance influences the choice of earnings management method (Cohen et al. 2008; Kothari et al. 2005). The poorer the performance of the firm, the keener will be the tendency to engage in earnings management by firms. Thus, we anticipate a negative coefficient on return on assets. Also, we include firm size to control for the existing variations in accruals behaviour between large and small firms (Gul, Fung and Jaggi, 2009).

Prior studies (Ashbaugh, Lafond, and Mayhew, 2003) indicate that small firms are more likely to engage in earnings management than large firms. Therefore, depending on the size of the firms in the sample, we expect a negative or positive association between earnings management and firm size. To secure external financing, prior studies (Chung and Kallupur, 2003; Johnson and Nelson 2002) indicate that management might manage reported earnings upwards. Therefore, we control for leverage, estimated as the ratio of long-term debt to total assets because prior studies indicate that managing earnings upwards allows firms to meet debts covenants (Zang, 2012; Badertscher, 2011; Yu, 2008; Sweeney, 1994). In addition, DeFond and Jiambalvo (1994) report that firms with a higher debt (leverage) have the tendency to manage earnings because of debts covenants, therefore a positive relationship between leverage and earnings management is expected. Furthermore, we control for firms reporting operational loss in the previous year because Francis and Yu (2009) observe that there is a positive relationship between earnings management and prior year losses but a negative relationship between firms reporting profits in the previous year and earnings management. However, the sign of operating loss can be negative or positive depending on whether earnings management is income decreasing or increasing.

To assess the extent of misclassification of core expenses, we include lagged core earnings $\left(C E_{t-1}\right)$ because of the unrelenting nature of core earnings. Again, asset turnover ratio $\left(A T O_{t}\right)$ is added to the model because Nassim and Penman (2001) report that there exists a negative relationship between profit margin and $A T O_{t}$. In addition, McVay (2006) indicates that inclusion of $A T O_{t}$ in the model (6) above is crucial because changes to the operating strategies are associated with firms that have large income-decreasing special items, for 
example, firms can change their profit and sales mix to affect the level of core earnings. We include $A C C R U A L S_{t-1}$, which are prior year operating accruals and $A C C R U A L S_{t}$ which are current year accruals in the model. Previous studies (Fan et al., 2010; McVay, 2006; Sloan, 1996) observe that earnings performance of firms is influenced by accruals and cash flows earnings components. These studies observe that accruals manipulation could result in high or low accruals figure, which can affect firm's performance. Therefore, we include accruals to ensure a good prediction of core earnings. Again, prior research (McVay, 2006; Anderson, Banker and Janakiraman, 2003) indicates that costs increase is associated with changes in activity level. We therefore include change in sales $\left(\triangle S A L E S_{t}\right)$ and the percentage change in sales $\left(N E G_{-} \triangle S A L E S_{t}\right)$, if $\triangle S A L E S$ is less than 0 , otherwise zero.

\subsection{Data Collection}

We collect financial data from all firms on the compustat database between 2004 and 2013. In line with prior research, data from specialised industries such as banks and insurances companies as well as other financial services were excluded from the datasets (Donelson et al., 2013; McGuire et al. 2012; Zang, 2012). Financial services companies with (Standard Industry Classification code (SIC) 60-69) are deleted as prior studies (eg. Francis and Yu, 2009; Maijoor and Vanstraelen, 2006) indicate that their accruals generating process differ significantly and they require specific accounting rules and requirements, including, the minimum capital requirements and specific regulations governing financial services companies. Again, firms with missing data and those with less than eight firm-year observations to estimate earnings management are excluded (Cohen and Zarowin, 2010; Francis and $\mathrm{Yu}, 2009)$. In addition, to shun bias resulting from the inclusion of insignificant firms in the sample, the paper excludes any observation with revenue less than $\$ 500,000$ (Ball and Shivakumar, 2008), thus reducing the number of firms and firm-year observations with all necessary variables to 1,616 and 11,105 respectively. The final sample is used to estimate discretionary accruals and other earnings management measures ${ }^{5}$. We obtain additional data from other sources including, Annual Reports, Audit Analytics, CRSP and I/B/E/S.

\footnotetext{
${ }^{5}$ Appendices B and C provide the detailed breakdown of the sampling procedure and firms' classification by year and industry.
} 
Table 3 below presents descriptive statistics for all dependent variables (ABNOR_ACCRUALS, REALMGMT1, REALMGMT2, and ABNOR_CORE) which are proxies for earnings management methods. Consistent with prior studies (McGuire et al., 2012; Omer et al., 2010) the univariate statistics appear similar to other distributions for all dependent variables, which are winsorized at the first and $99^{\text {th }}$ percentile.

Table 3: Descriptive Statistics for Accounting Data

\begin{tabular}{|c|c|c|c|c|c|c|c|}
\hline & Mean & $\begin{array}{l}\text { Std. } \\
\text { Dev. }\end{array}$ & Q1 & Median & Q3 & skewness & kurtosis \\
\hline \multicolumn{8}{|l|}{ Dependent Variables } \\
\hline ABNOR_ACCRUALS & -0.01 & 0.98 & -0.05 & -0.04 & 0.24 & -0.62 & 2.62 \\
\hline REALMGMT1 & -0.02 & 0.39 & -0.16 & -0.03 & 0.21 & -0.17 & 1.52 \\
\hline REALMGMT2 & -0.01 & 0.24 & -0.11 & -0.02 & 0.14 & -0.16 & 1.52 \\
\hline ABNOR_CORE & -0.01 & 0.69 & -0.03 & -0.01 & 0.03 & -0.15 & 1.5 \\
\hline \multicolumn{8}{|l|}{$\begin{array}{l}\text { Demographic Control } \\
\text { Variables }\end{array}$} \\
\hline POPN & 2.61 & 0.08 & 2.52 & 2.6 & 2.68 & -0.5 & 1.5 \\
\hline INCOME & 10.86 & 0.09 & 10.84 & 10.88 & 10.93 & -1.02 & 2.53 \\
\hline EDUC & 85.98 & 2.71 & 83.9 & 87.2 & 87.67 & -1.08 & 2.87 \\
\hline AGE & 40.44 & 1.83 & 40.02 & 40.35 & 41.89 & -0.84 & 2.94 \\
\hline MINORITY & 30.58 & 12.42 & 19.69 & 25.83 & 38.47 & 0.95 & 2.71 \\
\hline POLITICAL & 41.61 & 3.14 & 39 & 41 & 43 & 0.09 & 2.87 \\
\hline \multicolumn{8}{|l|}{$\begin{array}{l}\text { Firm-Level Control } \\
\text { Variables }\end{array}$} \\
\hline SIZE & 5.68 & 1.76 & 3.39 & 5.19 & 6.88 & 0.86 & 2.83 \\
\hline ANALYST_FOL & 2.91 & 1.4 & 2 & 3 & 4 & 0.28 & 2.03 \\
\hline ROA & -0.31 & 0.14 & -0.03 & 0.04 & 0.08 & -1.59 & 2.77 \\
\hline LEV & 0.15 & 0.16 & 0 & 0.1 & 0.25 & 0.89 & 2.67 \\
\hline BIG4 & 0.69 & 0.31 & 1 & 1 & 1 & -2.49 & 3.19 \\
\hline MBV & 2.01 & 1.21 & 1.02 & 1.75 & 2.91 & 0.49 & 1.98 \\
\hline LOSS & 0.48 & 0.5 & 0 & 0 & 1 & 0.06 & 1 \\
\hline OP_RISK & 0.65 & 16.35 & 0.23 & 0.5 & 0.86 & 0.91 & 2.79 \\
\hline RURAL & 2.9 & 0.12 & 2.82 & 2.88 & 2.98 & 0.72 & 2.91 \\
\hline BENCHMARK & 0.04 & 0.11 & -0.04 & 0.04 & 0.08 & -1.11 & 3.15 \\
\hline TENURE & 1.31 & 0.57 & 1.1 & 1.39 & 1.79 & -0.72 & 3.06 \\
\hline CHANGE_GDP & 1.89 & 1.65 & 0.8 & 1.7 & 2.7 & 0.89 & 3.29 \\
\hline INVESTMENT & 0.08 & 0.06 & 0.04 & 0.07 & 0.11 & 0.94 & 3.01 \\
\hline NOA & 0.78 & 1.26 & 0.39 & 0.49 & 0.88 & -0.16 & 1.57 \\
\hline
\end{tabular}

Notes: Descriptive statistics for demographic control variables in Table 3 are based on our sample of 790 U.S. Counties and the firm-level control variables are based on our sample of 11,105 firm-year observations. Continuous variables are winsorized at 1st and 99th percentile. All variables are defined below and in the Appendix A. Variables Definitions: ABNOR_ACCRUALS $=$ measure of abnormal accruals using the Modified-Jones model in equation 1 below. REALMGMT1 
$=$ calculated as the aggregate of abnormal discretionary expenditures $\left(A B N O R \_D E X^{6} P\right)$ and abnormal production costs $\left(A B N O R \_P C O S T\right)^{7} . R E A L M G M T 2=$ calculated as the aggregate of abnormal discretionary expenditure $\left(A B N O R \_D E X P\right)$ and abnormal cash flows $\left(A B N O R_{-} C A S H\right)^{8}$. The higher the value for REALMGMT1 and REALMGMT2, the higher the level of real earnings management. $A B N O R_{-} C O R E$ or $U N E X P_{-} C E=$ computed as the difference between reported core earnings (REP_CE) ${ }^{9}$ and expected core earnings $\left(\right.$ NOR_CE) ${ }^{10}$ for each firm. $P O P N=$ natural log of the estimate of the population for each US State in millions. INCOME = household income for each US State in ten thousands (\$) estimated by Census Bureau. EDUC = measure of the adult population in each US State with college education, estimated by Gallup interviews. $A G E=$ average age of residents in each US State, based on the responses from Gallup interviews. MINORITY= percentage of racial minorities in each US State, from responses to the Gallup interviews. POLITICAL = percentage of the adult population in each US State who is affiliated with the Republican Party, from Gallup interview response. SIZE= natural log of total assets scaled by consumer price index; $A N A L Y S T \_F O L=$ number of financial analysts following the firm in the $\mathrm{I} / \mathrm{B} / \mathrm{E} / \mathrm{S}$ summary file; $R O A=$ return on assets, measured as net income before extraordinary items divided by average total assets; $L E V=$ financial leverage, measured as total debts scaled by total equity; $B I G 4=$ a value of 1 if the firm was audited by BIG4 audit firm for a firm year observation, otherwise zero; $M B V=$ measured as total assets divided by market capitalization; $L O S S=$ indicator variable that equals 1 if income before extraordinary items was negative in the current or previous two fiscal years, and 0 otherwise; $O P_{-} R I S K=$ estimated as five year rolling standard deviation of operating cash flows estimated from both current and previous four years; $R U R A L=$ Indicator variable that equals 1 if the firm is headquartered outside the 490 largest counties in the sample, and 0 otherwise; BENCHMARK = an indicator value is if (a) net income scaled by total assets is more than or equal to 0 and less than 0.01 . Alternatively, if the change in net income scaled by total assets from previous year to current year is greater than or equal to 0 and less than 0.01 , and 0 otherwise; $T E N U R E=$ natural $\log$ of the number of years the auditor has been with the firm; CHANGE_GDP $=$ annual percentage change in GDP; INVESTMENT = percentage of capital expenditure at the beginning of the year (t) to total net property, plant and equipment at the end of the year (t); NOA = sum of shareholders' equity less cash and marketable securities plus total debt at the beginning of the year, scaled by total assets at the beginning of the year.

Table 3 also presents descriptive statistics for the county-level demographic control variables (POPN, INCOME, EDUC, AGE, MINORITY, POLITICAL). The average age is approximately 40 and $86 \%$ of the population have a minimum of college education. Also, approximately $42 \%$ of the population are affiliated with Republican Political Party and an average minority population is roughly $31 \%$. To control for skewness and kurtosis in income and population variables in line with previous studies (McGuire et al., 2012; Omer et al., 2010), the natural log of each county's income and population was taken. The original data shows that on average, each county has 3.9 million people and the average household income is $\$ 91,700$ per year. Again, Table 3 presents univariate statistics for firm-level control variables (SIZE, ANALYST_FOL, ROA, LEV, BIG4, MBV, LOSS, OP_RISK, RURAL,

\footnotetext{
${ }^{6}$ ABNOR_DEXP - estimated by regressing discretionary expenses on the inverse of lagged total assets and lagged sales scaled by lagged total assets. The figure for $\left(A B N O R_{-} D E X P\right)$ is multiplied by negative one $(-1)$, consequently, a higher $\left(A B N O R_{-} D E X P\right)$ figure represents higher real earnings management.

${ }^{7}$ ABNOR_PCOST - estimated by regressing PCOST on the inverse of lagged total assets, sales scaled by lagged total assets, change in sales scaled by lagged total assets. The figure for $\left(A B N O R \_P C O S T\right)$ is multiplied by negative one $(-1)$, consequently, a higher $\left(A B N O R \_P C O S T\right)$ figure represents higher real earnings management.

8 ABNOR CASH- estimated by regressing CASFO scaled by lagged total assets on the inverse of lagged total assets, sales scaled by lagged total assets, change in sales scaled by lagged total assets. The figure for (ABNOR_ CASH) is multiplied by negative one (-1), consequently, a higher ( $A B N O R_{-}$CASH) figure represents higher real earnings management.

9 REP_CE- estimated as sales - cost of goods sold - selling, general and administration expenses. Depreciation and Amortization are excluded from Cost of Sales, Selling, General and Administrative Expenses.

${ }^{10}$ NOR_CE- is the core earnings that is actually expected to occur in the normal course of business activity devoid of classification shifting.
} 
BENCHMARK, TENURE, CHANGE_GDP, INVESTMENT, NOA). ${ }^{11}$ The univariate results are similar to distributions in prior research. Approximately, 69\% of the Big 4 auditors examine the financial records of the firms, $48 \%$ of the firms reported loss in the last two years or the current financial year. Approximately, an average of 3 analysts follows the firms and $2.9 \%$ of the firm-year observations are from rural counties. ${ }^{12}$

\section{RESEARCH DESIGN AND EMPIRICAL METHODOLOGY}

\subsection{Earnings Management Metrics}

Due to the difficulty in detecting earnings management, in line with prior research, we use different measures to proxy for the three methods of earnings management.

\subsection{Measuring Accrual-Based Earnings Management}

We use the Modified-Jones model to estimate discretionary accruals in line with prior studies (Ball, 2013; Gerakos \& Kovrijnykh, 2013; McGuire et al., 2012; Cohen and Zarowin, 2010; Dechow et al. 1995; Defond and Jiambalvo, 1994). This allows us to decompose discretionary accruals from non-discretionary accruals by adjusting change in sales for the change in receivables. Yearly, we estimate the model for every firm and industry classified by its 2-digit SIC code. This procedure partially enables us to regulate the changes in economic conditions that affect industries and total accruals so that the coefficients differ across time. Again, we subtract change in accounts receivables $\left(\Delta A R_{i t}\right)$ from change in sales $\left(\triangle S A L E S_{i t}\right)$ before estimating the yearly residuals for all firm-year observations in the same two-digit SIC code. We estimate total accruals $\left(\mathrm{TAC}_{\mathrm{it}}\right)$ defined as income before

\footnotetext{
${ }^{11}$ Consistent with McGuire et al., (2012), the correlations among religiosity (REL) and the demographic control variables in each county are mainly negative with the exception of residents in the counties who are affiliated with Republican Political Party and percentage of racial minority in each county, from the surveys by ASARB. Results are available under request.

${ }^{12}$ Consistent with McGuire et al. (2012), there is negative correlation between religiosity (REL) and accrual-based earnings management (ABNOR_ACCRUALS) but positive correlation between religiosity (REL) and proxies' for real earnings management (REALMGMT1 and REALMGMT2). We also find positive correlation between religiosity (REL) and classification shifting (ABNOR_CORE) . This suggests that managers in highly religious environment are more likely to engage in classification shifting because: (i) there is an absence or limited external scrutiny and monitoring from auditors and regulators (ii) again, classification shifting does not change the bottom-line profit. The firm-level control variables are associated with ABNOR_ACCRUALS, REALMGMT1, REALMGMT2 and ABNOR_CORE. For example, SIZE is negatively correlated with religiosity (REL) and demonstrates the risk appetite of a firm manager who works in highly religious environment. Again, SIZE, ROA and BIG4 are negatively and significantly correlated with ABNOR ACCRULAS, which indicates that large firms with high ROA, that are audited by the BIG4 with close external monitoring are less likely to manage earnings through-accrual based earnings management. The correlations among the dependent variables, firm-level control variables and religiosity range from significant; less-significant to insignificant. Again, the correlation matrix shows that there is no multi-collineriaty between the variables used in the model because the co-efficients are very low. Therefore, we include all the variables in our model of estimation. The analysis will help explain the extent of the relationships and highlights the magnitude of including these control variables.
} 
extraordinary items but after adjusting for operating cash flow scaled by lagged total assets. The Modified-Jones model is in the form of:

$$
\frac{\mathrm{TAC}_{\mathrm{it}}}{\mathrm{TA}_{\mathrm{it}-1}}=\beta_{0}\left(\frac{1}{\mathrm{TA}_{\mathrm{it}-1}}\right)+\beta_{1}\left(\frac{\Delta \mathrm{SALES}_{\mathrm{it}}-\Delta \mathrm{REC}_{\mathrm{it}}}{\mathrm{TA}_{\mathrm{it}-1}}\right)+\beta_{2}\left(\frac{\mathrm{PPE}_{\mathrm{it}}}{\mathrm{TA}_{\mathrm{it}-1}}\right)+\varepsilon_{\mathrm{it}}
$$

Where $T A C_{i t}=$ EBXI-CASFO; where EBXI is the earnings before extraordinary items and discontinued operations; CASFO is the cash flow from operational activities scaled by $T A_{i t-1}$, (lagged total assets), $\triangle S A L E S_{i t}$ (change in sales) is scaled by $T A_{i t-1}$, lagged total assets, $\Delta A R_{i t}$ is (change in accounts receivables) and $P P E_{i t}$ is net property, plant and equipment, scaled by $T A_{i t-1}$ lagged total assets. $\boldsymbol{\varepsilon}_{\mathbf{i t}}$ is the residuals representing the measure of earnings management as dependent variable in the model. In line with prior studies (Kothari et at., 2005; White, 1980), we use assets as a deflator to mitigate heteroskedasticity in residuals but not to eliminate it and also include a constant in the model estimation in order (i) to manage heteroskedasticity not dealt with by using assets as a deflator and (ii) to minimise the effect of omitted variables (Brown, Lo and Lys (1999). We use discretionary abnormal accruals and anticipate that religious managers would be less inclined to manipulate accruals and for that matter reported income upwards. Based on previous studies cited above on religiosity and earnings management, we predict a negative relationship between religiosity and abnormal accruals.

In addition, in the robustness test, we estimate discretionary abnormal accruals using other definitions of accruals used in the literature. We replace total accruals estimated in the modified-Jones model in equation (1) by working capital accruals (WC_ACRUALS) defined as earnings before extraordinary items plus depreciation and amortisation minus cash flows from operating activities (Dechow et al., 2012; Peasnell et al., 1999). The revised modifiedJones model is as follows:

$\left(W C_{-} A C C R U A L S\right)=\beta_{0}\left(\frac{1}{\mathrm{TA}_{\mathrm{it}-1}}\right)+\beta_{1}\left(\frac{\Delta \mathrm{SALES}_{\mathrm{it}}-\Delta \mathrm{REC}_{\mathrm{it}}}{\mathrm{TA}_{\mathrm{it}-1}}\right)+\beta_{2}\left(\frac{\mathrm{PPE}_{\mathrm{it}}}{\mathrm{TA}_{\mathrm{it}-1}}\right)+\varepsilon_{\mathrm{it}}$

Where $W C_{-} A C C R U A L S_{i t}=\mathrm{IB}+\mathrm{DP}-\mathrm{CASFO}$; and IB is the earnings before extraordinary items; DP are depreciation and amortisation and CASFO is cash flow from operational 
activities. The COMPUSTAT data items for working capital estimations are $=($ Data18 + Data 14-Data 308). Kothari et al (2005) used performance-matched discretionary accruals and report that the modified-Jones model is severely mis-specified for samples of firms experiencing non-random performance. However, Dechow et al (2012) argue that Kothari et al (2005) performance-matched accruals model explains only $10 \%-12 \%$ of the variations in accruals and therefore distort the measure of discretionary accruals. They indicate further that Kothari et al (2005) performance-matching model is prone to management discretion and bias. Consequently, this study maintains the modified-Jones model and re-defines the measure of the discretionary abnormal accruals using working capital accruals to establish the association between religiosity and accruals based earnings management.

\subsection{Measuring Real Activities Earnings Management}

As in McGuire et al. (2012), we use two measures to proxy for real activities earnings management. Initially, we compute and aggregate abnormal cash flows (ABNOR_CASH), abnormal production costs (ABNOR_PCOST) and abnormal discretionary expenses (ABNOR_DEXP) for each firm and industry classified by its 2-digit SIC code using the model developed by Dechow et al. (1991). Abnormal Cash flows (ABNOR_CASH) is computed as the deviations from the predicted values from the industry-year regression. We run the following regression model for each industry and year in line with prior studies (McGuire et al. 2012; Zang, 2012; Cohen and Zarowin, 2010; Cohen et al. 2008; Roychowdhury, 2006). The following regression model is used:

$\frac{\mathrm{CASFO}_{\mathrm{it}}}{\mathrm{TA}_{\mathrm{it}-1}}=\beta_{0}\left(\frac{1}{\mathrm{TA}_{\mathrm{it}-1}}\right)+\beta_{1}\left(\frac{\mathrm{SALES}_{\mathrm{it}}}{\mathrm{TA}_{\mathrm{it}-1}}\right)+\beta_{2}\left(\frac{\Delta \mathrm{SALES}_{\mathrm{it}}}{\mathrm{TA}_{\mathrm{it}-1}}\right)+\varepsilon_{\mathrm{it}}$

Where CASFO is the cash flow from operational activities (Data308 - Data124) $T A_{i t-1}$, lagged total assets, $\triangle S A L E S_{i t}$ is change in sales. As indicated above, sales represents annual sales revenue (Data 12) and total assets (Data6) is the aggregate of both non-current and current assets. The figure for $\left(A B N O R_{-} C A S H\right)$ is multiplied by negative one $(-1)$ in line with previous. Therefore, a higher (ABNOR_CASH) figure represents a higher real earnings management. Again, we estimate abnormal production costs (ABNOR_PCOST) as the 
deviations from predicted values from the industry-year regression. Following prior studies, the following regression model is used to compute abnormal production:

$\frac{\boldsymbol{P C O S T} \boldsymbol{C}_{i t}}{T A_{i t-1}}=\beta_{0}\left(\frac{1}{T A_{i t-1}}\right)+\beta_{1}\left(\frac{\boldsymbol{S A L E S}_{i t-1}}{T A_{i t-1}}\right)+\beta_{2}\left(\frac{\Delta S A L E S_{i t}}{T A_{i t-1}}\right)+\left(\frac{\Delta S A L E S_{i t-1}}{T A_{i t-1}}\right)+\varepsilon_{i t}$

Where, PCOST is the aggregate of cost of sales (Data41) and change in inventory during the year (Data 3). The definitions of other variables in the model remain the same as above. Again, consistent with prior research (McGuire et al. 2012; Zang, 2012; Cohen and Zarowin, 2010; Cohen et al. 2008; Roychowdhury, 2006) the figure for (ABNOR_PCOST) is multiplied by negative one (-1), consequently, a higher (ABNOR_PCOST) figure represents higher real earnings management.

In addition, we model discretionary expenses as a function of lagged sales to avoid the problem of significantly lower residuals from running regression using current sales. Thereafter, abnormal discretionary expenses (ABNOR_DEXP) is computed from the predicted values from the industry-year regression. Following prior studies, we estimate abnormal discretionary expenses using the following regression model:

$\frac{D_{-} E X P_{i t}}{T A_{i t-1}}=\beta_{0}\left(\frac{1}{T A_{i t-1}}\right)+\beta_{1}\left(\frac{\text { SALES }_{i t-1}}{T A_{i t-1}}\right)+\varepsilon_{i t}$

Where D_EXP is the aggregate of advertising expenses (Data 45), R\& D expenses (Data 46) and SG \& A expenses (Data 189). Again, following previous studies (McGuire et al. 2012; Zang, 2012; Cohen and Zarowin, 2010; Cohen et al. 2008; Roychowdhury, 2006), where SG $\& A$ is available but advertising and R\&D expenses are not available, the value of zero is given. Also, in line with prior studies, the figure for (ABNOR_DEXP) is multiplied by negative one (-1), consequently, a higher (ABNOR_DEXP) figure represents higher real earnings management.

The residuals from abnormal cash flows (ABNOR_CASH), abnormal production cost (ABNOR_PCOST) and abnormal discretionary expenses (ABNOR_DEXP) are aggregated as proxies for two measures of real-earnings management. As previously indicated, firms that manipulate earnings upwards are characterised by unusually low cash flows from operations, low discretionary expenses and high production costs. As in prior studies, the first proxy to 
measure real activities earnings management is REALMGMT1, abnormal discretionary expenses (ABNOR_DEXP) is multiplied by negative (-1) and the results added to abnormal production cost (ABNOR_PCOST). The higher the aggregate of these two measures, the stronger the evidence that the firm is cutting expenses and therefore involved in real-activities earnings management. The second proxy for real-activities earnings management is REALMGMT2. Again, consistent with prior studies, we compute the aggregate of abnormal cash flows (ABNOR_CASH) and abnormal discretionary expenses (ABNOR_DEXP) after multiplying each of them by negative (-1). These measures are multiplied by negative one (1) to assess the extent of manipulations in sales and discretionary expenses as the higher the results, the more likely the firm is engaged in managing earnings upwards. Cohen and Zarowin (2010) observe that the individual variables to be used to compute the proxies for real activities earnings management has varying impact and therefore can change or provide misleading results when aggregated. In the robustness check, we report on both aggregated measures and individual proxies for real earnings management to assess the impact of religiosity on each of the proxies for real earnings management.

\subsection{Measuring Classification Shifting}

To estimate normal or expected core earnings (NOR_CE), we rely on McVay (2006) model as adopted by Fan et al. (2010). We focus on special items to assess the extent of earnings management and run the following regression model using both industry and fiscal year estimates to estimate unexpected core earnings ${ }^{13}$ :

$$
\begin{gathered}
N O R_{-} C E_{t}=\beta_{0}+\beta_{1} C E_{t-1}+\beta_{2} A T O_{t}+\beta_{3} A C C R U A L S_{t-1}+\beta_{4} A C C R U A L S_{t} \\
+\beta_{5} \Delta S A L E S_{t}+\beta_{6} N E G_{-} \Delta S A L E S_{t}+\varepsilon_{t}
\end{gathered}
$$

where; NOR_CE $E_{t}$ is the current year core earnings, calculated as (Sales - Cost of Goods Sold - Selling, General and Administrative Expenses)/Sales. $C E_{t-1}$ is the lagged core earnings; $A T O_{t}$ is the asset turnover ratio. Again, in line with prior studies (McVay, 2006; Fan et al., 2010), we include $A C C R U A L S_{t-1}$ which is prior year operating accruals and ACCRUALS which is current year accruals. $\triangle S A L E S_{t}$ is change in sales and $N E G_{-} \triangle S A L E S_{t}$ is the

\footnotetext{
${ }^{13}$ Unexpected core earnings and abnormal core earnings are used in this paper interchangeably.
} 
percentage change in sales, where $\triangle S A L E S$ is less than 0 , otherwise zero. Model 6 is run cross-sectionally to obtain estimates for the coefficients which are then used to calculate normal core earnings for each firm using its variables. The unexpected core earnings (UNEXP_CE) is then computed as the difference between reported core earnings (REP_CE) and expected core earnings (NOR_CE) for each firm. Again, we run model (7) to test whether firms see classification shifting as a viable earnings management method. A positive relationship between unexpected core earnings and special items is an evidence of classification shifting. When firms' engage in classification shifting, unexpected core earnings increases with special items and thus we expect $\beta_{1}$ to be positive.

$$
\text { UNEXP_CE } E_{t}=\beta_{0}+\beta_{1} \% S P E C_{-} I T E M S_{t}+\beta_{2} \text { CONTROLVARIABLES }+\varepsilon_{t} \text {, }
$$

where UNEXP_CE $E_{t}$, is the unexpected core earnings and \%SPEC_ITEMS $S_{t}$ is incomedecreasing special items scaled by sales. Special item can be positive or negative, however, where special items are positive, it corresponds to income-decreasing otherwise income increasing and should be set to zero (Fan et al., 2010; McVay, 2006).

Furthermore, we interact religiosity (REL) with special items (SPEC_ITEMS) to generate a new variable RELSPEC_ITEMS in model (8) to establish the relationship between religion and special items. We anticipate a positive association between religiosity and special items and therefore the coefficient of RELSPEC_ITEMS should be positive in line with the hypothesis.

$$
\begin{aligned}
& \text { UNEXP_CE }{ }_{T}=\beta_{0}+\beta_{1} \% \text { SPEC_ITEMS }_{\mathrm{t}}+\beta_{2} \text { RELSPEC }_{-} \text {ITEMS }_{t} \\
& +\beta_{3} \text { CONTROLVARIABLES }+\varepsilon_{t}
\end{aligned}
$$

We exclude current accruals from equation (6) in McVay (2006) model to assess the effect of religious social norms on classification shifting. Recent studies (Fan et al., 2010; Barua and Cready, 2008; McVay, 2008) attribute McVay's estimation of expected core earnings to model bias because of the inclusion of contemporaneous accruals in the formation of expected core earnings values. These studies argue that the inclusion of current accruals results in the creation of a mechanical bias leading to a positive association between unexpected core earnings (dependent variable) and special items (independent variable). This therefore, suggests that the misclassification of core earnings into special items reported by 
McVay (2006) is not classification shifting but symbolic of model bias. Thus, the Fan et al (2010) model without contemporaneous accruals is shown below:

$$
\begin{gathered}
C E_{t}=\beta_{0}+\beta_{1} C E_{t-1}+\beta_{2} A T O_{t}+\beta_{3} A C C R U A L S_{t-1}+\beta_{5} \Delta S A L E S_{t} \\
+\beta_{6} N E G_{-} \Delta S A L E S_{t}+\varepsilon_{t}
\end{gathered}
$$

In the further supplemental analyses, we estimate the validity and results for both McVay (2006) and Fan et al (2010) models to assess the impact of religiosity on classification shifting.

\section{Testing the Relationship between Religiosity and Earnings Management}

This study investigates the impact of religiosity on earnings management methods using McGuire et al. (2012) model to establish the extent to which religiosity of the firm's environment affects earnings management. The model is in the form:

$$
\begin{aligned}
& \text { EARNINGSMGMT }=\beta_{0}+\beta_{1} R E L_{1}+\beta_{2} P_{O P N_{2}}+\beta_{3} \text { INCOME }_{3}+ \\
& \beta_{4} \text { EDUC }_{4}+\beta_{5} \text { POLITICS }_{5}+\beta_{6} A G E_{6}+ \\
& \beta_{7} \text { MINORITY }_{7}+\beta_{8} \text { SIZE }_{8}+\beta_{9} \text { ANALYST }_{F_{2} L_{9}}+ \\
& \beta_{10} R O A_{10}+\beta_{11} L E V_{11}+\beta_{12} B I G 4_{12}+\beta_{13} B M V_{13}+\beta_{14} L O S S_{14}+ \\
& \beta_{15} \text { OP }_{\text {RISK }} 15+\beta_{16} R_{U R A L_{16}}+\beta_{17} \text { BENCHMARK }_{17}+\beta_{18} \text { TENURE }_{18}+ \\
& \beta_{19} \text { CHANGE }_{G D P_{19}}+\beta_{20} \text { INVESTMENT }_{20}+\beta_{21} \text { NOA }_{21}+ \\
& \beta_{22} \text { IndustryIndicators } 22+\varepsilon
\end{aligned}
$$

The definitions of the variables are provided in the appendix. EARNINGSMGMT is used to proxy for accrual-based, real-activities and classification shifting earnings management. Firstly, we proxy for accruals-based earnings management and compute abnormal accruals (ABNOR_ACC) using the Modified-Jones model. We predict that there will be negative relationship between religiosity and accrual-based earnings management, that is, religious managers would be less inclined to manipulate accruals and for that matter reported income upwards. Prior studies (eg. McGuire et al. 2012; Hribar and Nicholas, 2007) observe that using absolute discretionary accruals can provide misleading results but making use of signed accruals establishes a clear association between managers religiosity and the method of managing earnings upwards. 
In addition, we use two proxies to measure real activities earnings management by aggregating abnormal cash flows, abnormal production costs and abnormal discretionary expenses for each firm ((McGuire et al. 2012). The first of the two proxies for real earnings management is the aggregate of abnormal discretionary expenses and abnormal production cost (REALMGMT1). The second proxy for real earnings management is estimated as the total of abnormal discretionary expenses and abnormal cash flows (REALMGMT2) in line with prior research (Zang, 2012; McGuire et al. 2012; Cohen and Zarowin, 2010). To proxy for classification shifting, we examine the classification of core expenses into special items within the income statement as an earnings management tool (McVay, 2006; Fan et al., 2010). Core expenses and special items are the main focus because core expenses are relatively steady, while special items are infrequent or unusual in nature (Fan et al., 2010; McVay, 2006; Doyle et al., 2003). Therefore, refusal to separate core expenses from special items has the potential to mislead users of financial statements in decision-making. We posit that managers in a highly religious environment wishing to maximise reported financial performance will be more inclined to misclassify core expenses into special items than using real-activities and accrual-based earnings because the former does not change GAAP earnings. Again, the bottom-line reported net income remains the same, thus misleading regulators and auditors not to scrutinize the income statement items (Fan et al. 2010; McVay, 2006; Nelson et al. 2002). Initially, we focus on the relationship between unexpected core earnings (UNEXP_CE) and special items (SPEC_ITEMS) and predict a positive relationship between them. Thus income-decreasing special items are considered and the difference between expected core earnings and reported core earnings are estimated as unexpected core earnings.

To test our hypotheses, we examine the coefficient of the religiosity of firms' environment (REL) and expect that religious managers in their bid to improve performance and manage core earnings upwards will shift expenses that should be classified as core expenses to special items because they deem misclassification as more ethical, not fraudulent, and not subject to the scrutiny of auditors and regulators. Again, misclassification of core expenses does not change the bottom line reported profit. Therefore, we anticipate positive coefficient on $R E L$ and classification shifting; negative relationship between $R E L$ and accrual-based earnings management but positive association between $R E L$ and real earnings management. 
Again, to assess that our initial results are not influenced by corporate governance, we control for corporate governance variables and exclude BIG4 auditors and audit tenure from our original model (model 10) above because of multi-collinearity. In particular, we use board size (BODSIZE), number of independent directors (BODIND), CEO tenure (CEOTEN) and audit committees (AUCOM) as proxies for corporate governance. Secondly, we examine the interaction between religiosity and corporate governance variables to assess their impact on earnings management by multiplying religiosity by the proxies for corporate governance to derive four new variables (RELBODSIZE; RELBODIND; RELAUCOM and RELCEOTEN) to be included in the model.

\subsection{Regression Results and Discussions}

Following the above, we run series of regressions using fixed effects to account for heterogeneity across firms. The summary of the final regression results of each dependent variable are presented in Table 4. Based on hypothesis 1, we show that religiosity (REL) is significantly and negatively associated with abnormal accruals (ABNOR_ACCRUALS; Pvalue $=0.001$, this indicates that religiosity in a firm's environment mitigates accruals earnings management. This finding is consistent with (McGuire et al., 2012; Callen et al., 2011; Dyreng et al., 2009) who observe that accruals based earnings management is frowned by highly religious managers because they deem it unethical business practice. Again, such earnings management are prone to regulators and auditors' scrutiny. In contrast, in hypothesis 2, we observe a positive association between religiosity and the two measures of realactivities earnings management (REALMGMT1; P-value $=0.002 \&$ REALMGMT2; P-value $=0.001)$, suggesting that managers in highly religious environment consider real-earnings management as less dangerous and morally upright than accruals manipulation because of limited scrutiny from external monitors. Again, real activities manipulation does not violate the GAAP and accounting regulations (McGuire et al. 2012).

In line with hypothesis 3, we find that the impact of religiosity on classification shifting is significantly positive $\left(A B N O R \_C O R E ;\right.$ P-value $\left.=0.003\right)$. Previous research (Zalata and Roberts, 2015; Fan et al., 2010; McVay, 2006) observed that classification shifting and accruals based earnings management result from financial reporting decision. Therefore, it is possible that their association with religiosity of the firm's environment will be the same and 
for that matter negative. However, the result shows a positive association between classification shifting and religiosity of the firms' environment because classification shifting does not change GAAP net income, is not subject to GAAP violation and scrutiny of external monitors. Also, future earnings are unaffected as there are no reversals in accruals or reduction in future earnings from lost opportunities (Athanasakou, Strong \& Water, 2009). Therefore, it is possible that religious managers deem it acceptable and ethically correct to engage in misclassification of expenses to change the bottom line earnings. Our paper is the first to establish the association between religiosity and classification shifting. In the robustness test, we drop current accruals from McVay (2006) model in line with Fan et al (2010). However, the inferences remain the same. 
TABLE 4: Relationship Between Religiosity and Accrual-Based, Real-Activities versus Classification Shifting Earnings Management

\begin{tabular}{|c|c|c|c|c|}
\hline VARIABLE & ABNOR_ACC & REALMGMT1 & REALMGMT2 & ABNOR_CORE \\
\hline CONSTANT & $0.724 * * *$ & $0.679 * * *$ & $0.571 * *$ & $0.560 * * *$ \\
\hline REL & $\begin{array}{l}-0.059 * * * \\
(-3.406)\end{array}$ & $\begin{array}{l}0.348 * * * \\
(3.240)\end{array}$ & $\begin{array}{l}0.049 * * * \\
(3.396))\end{array}$ & $\begin{array}{l}0.095 * * * \\
(2.850)\end{array}$ \\
\hline SIZE & $\begin{array}{l}-0.067 * * * \\
(-9.600)\end{array}$ & $\begin{array}{l}-0.544 * * * \\
(-11.660)\end{array}$ & $\begin{array}{l}-0.556 * * * \\
(-12.540)\end{array}$ & $\begin{array}{l}-0.024 * * * \\
(-3.102)\end{array}$ \\
\hline ANALYST_FOL & $\begin{array}{l}-0.004 * \\
(-1.648)\end{array}$ & $\begin{array}{c}-0.012 \\
(-0.770)\end{array}$ & $\begin{array}{l}-0.023 \\
(-1.580)\end{array}$ & $\begin{array}{l}-0.002 \\
(-0.640)\end{array}$ \\
\hline ROA & $\begin{array}{l}-0.171 * * * \\
(-3.263)\end{array}$ & $\begin{array}{l}-0.951 * * * \\
(-3.141)\end{array}$ & $\begin{array}{c}-0.395 * * * \\
(-3.029)\end{array}$ & $\begin{array}{l}-0.563 * * * \\
(-9.670)\end{array}$ \\
\hline LEV & $\begin{array}{l}0.092 * * * \\
(4.530)\end{array}$ & $\begin{array}{l}0.248^{*} \\
(1.820)\end{array}$ & $\begin{array}{c}0.055 \\
(0.430)\end{array}$ & $\begin{array}{l}0.074 * * * \\
(3.250)\end{array}$ \\
\hline BIG4 & $\begin{array}{l}-0.011 * * \\
(-2.090)\end{array}$ & $\begin{array}{l}-0.068 \\
(-1.040)\end{array}$ & $\begin{array}{c}-0.059 \\
(-0.920)\end{array}$ & $\begin{array}{l}-0.020^{*} \\
(-1.800)\end{array}$ \\
\hline MBV & $\begin{array}{l}-0.013 * * * \\
(-6.080)\end{array}$ & $\begin{array}{l}-0.146^{* * * *} \\
(-10.150)\end{array}$ & $\begin{array}{c}-0.100 * * * \\
(-7.400)\end{array}$ & $\begin{array}{l}-0.036^{* * *} \\
(-3.194)\end{array}$ \\
\hline LOSS & $\begin{array}{c}0.005 \\
(1.140)\end{array}$ & $\begin{array}{l}0.052 * \\
(1.760)\end{array}$ & $\begin{array}{c}0.073 * * \\
(2.580)\end{array}$ & $\begin{array}{l}0.027 * * * \\
(5.470)\end{array}$ \\
\hline OPERA_RISK & $\begin{array}{l}0.014 * * * \\
(6.490)\end{array}$ & $\begin{array}{l}0.037 * * * \\
(2.620)\end{array}$ & $\begin{array}{l}0.041 * * * \\
(2.990)\end{array}$ & $\begin{array}{l}0.005^{* *} \\
(2.030)\end{array}$ \\
\hline RURAL & $\begin{array}{c}0.005 \\
(1.530)\end{array}$ & $\begin{array}{l}-0.024 \\
(-1.050)\end{array}$ & $\begin{array}{l}-0.015 \\
(-0.720)\end{array}$ & $\begin{array}{l}-0.005 \\
(-1.400)\end{array}$ \\
\hline BENCHMARK & $\begin{array}{c}0.034 \\
(0.630)\end{array}$ & $\begin{array}{l}-0.644^{*} \\
(-1.770)\end{array}$ & $\begin{array}{l}-0.532 \\
(-1.550)\end{array}$ & $\begin{array}{c}0.102 \\
(1.600)\end{array}$ \\
\hline TENURE & $\begin{array}{c}-0.002 \\
(-0.560)\end{array}$ & $\begin{array}{c}-0.009 \\
(-0.510)\end{array}$ & $\begin{array}{c}-0.002 \\
(-0.110)\end{array}$ & $\begin{array}{c}-0.000 \\
(-0.170)\end{array}$ \\
\hline CHANGE_GDP & $\begin{array}{l}-0.000 \\
(-0.040)\end{array}$ & $\begin{array}{l}-0.012 * \\
(-1.910)\end{array}$ & $\begin{array}{c}-0.007 \\
(-1.280)\end{array}$ & $\begin{array}{l}-0.001 \\
(-0.950)\end{array}$ \\
\hline INVESTMENT & $\begin{array}{l}-0.378 * * * \\
(-9.830)\end{array}$ & $\begin{array}{l}0.498^{*} \\
(1.940)\end{array}$ & $\begin{array}{c}0.147 \\
(0.600)\end{array}$ & $\begin{array}{l}0.466 * * \\
(2.100)\end{array}$ \\
\hline NOA & $\begin{array}{l}0.030 * * * \\
(4.930)\end{array}$ & $\begin{array}{l}0.106 * * \\
(2.580)\end{array}$ & $\begin{array}{l}0.169 * * * \\
(4.320)\end{array}$ & $\begin{array}{l}0.030 * * \\
(2.380)\end{array}$ \\
\hline POPN & $\begin{array}{l}-1.110 \\
(1.570)\end{array}$ & $\begin{array}{c}-0.864 \\
(-0.180)\end{array}$ & $\begin{array}{c}-0.353 \\
(-0.520)\end{array}$ & $\begin{array}{c}0.522 \\
(0.660)\end{array}$ \\
\hline INCOME & $\begin{array}{l}-0.121 * * \\
(-2.600)\end{array}$ & $\begin{array}{l}-0.544^{*} \\
(-1.750)\end{array}$ & $\begin{array}{c}-0.418 \\
(-1.420)\end{array}$ & $\begin{array}{l}-0.031 \\
(-0.600)\end{array}$ \\
\hline EDUC & $\begin{array}{l}-0.550 * * * \\
(-5.010)\end{array}$ & $\begin{array}{l}-0.989 * * * \\
(-4.120)\end{array}$ & $\begin{array}{c}-0.633 * * * \\
(-6.650)\end{array}$ & $\begin{array}{l}1.169 * * * \\
(9.570)\end{array}$ \\
\hline AGE & $\begin{array}{l}0.556 * * * \\
(4.570)\end{array}$ & $\begin{array}{l}0.660 * * \\
(2.040)\end{array}$ & $\begin{array}{l}0.781 * * * \\
(3.600)\end{array}$ & $\begin{array}{c}-0.615 * * * \\
(-4.540)\end{array}$ \\
\hline POLITICAL & $\begin{array}{l}0.002 * * \\
(2.690)\end{array}$ & $\begin{array}{c}0.001 \\
(0.200)\end{array}$ & $\begin{array}{c}0.001 \\
(-0.020)\end{array}$ & $\begin{array}{l}-0.001 \\
(-1.440)\end{array}$ \\
\hline MINORITY & $\begin{array}{l}-0.019 \\
(-1.020)\end{array}$ & $\begin{array}{c}0.156 \\
(1.240)\end{array}$ & $\begin{array}{c}0.117 \\
(0.980)\end{array}$ & $\begin{array}{c}0.042 * * \\
(1.990)\end{array}$ \\
\hline Industry Fixed Effects & Yes & Yes & Yes & Yes \\
\hline $\begin{array}{l}\text { Observations } \\
\text { R-square (overall) }\end{array}$ & $\begin{array}{c}8,605 \\
0.34\end{array}$ & $\begin{array}{l}7,966 \\
0.09\end{array}$ & $\begin{array}{c}8,605 \\
0.15\end{array}$ & $\begin{array}{c}8,573 \\
0.26\end{array}$ \\
\hline
\end{tabular}

Notes: We use $*, * *, * * *$ in a two tailed test to respectively indicate statistical significance at 10 percent, 5 percent and 1 percent levels; We estimate Model 1, 2, 3, and 4 using fixed effects regression; We show co-efficient estimates above and t- 
statistics below in brackets; $A B N O R \_A C C R U A L S=$ measure of abnormal accruals using the Modified-Jones model in equation 1; REALMGMT1 = calculated as the aggregate of abnormal discretionary expenditures $\left(A B N O R \_D E X P\right)$ and abnormal production costs $\left(A B N O R \_P C O S T\right)$. REALMGMT2 = calculated as the aggregate of abnormal discretionary expenditure $\left(A B N O R_{-} D E X P\right)$ and abnormal cash flows $\left(A B N O R_{-} C A S H\right)$. The higher the value for REALMGMT1 and REALMGMT2, the higher the level of real earnings management (Cohen and Zarowin, 2010). ABNOR_CORE or UNEXP_CE = computed as the difference between reported core earnings (REP_CE) and expected core earnings (NOR_CE) for each firm (McVay, 2006). All other variables are defined above and in the Appendix A.

We find that the firm-level control variables are associated with the managers methods of managing earnings. For example, ROA is negatively and significantly (1\%) related to abnormal accruals, real-activities and classification shifting earnings manipulations, suggesting that managers in religious environment are more likely to manage reported earnings upwards when the firm performs poorly. Again, analyst following (ANALYST_FOL) is negatively related to three dependent variables but insignificantly related to ABNOR_CORE, suggesting that religious managers are less likely to manage reported earnings when analysts monitor their performance. Similarly, SIZE is negatively and significantly (at 1\% level) associated with our proxies for earnings management, indicating that the sample includes larger firms than smaller firms. Ashbaugh et al. (2003) observe that small firms are more likely to manipulate reported profits than large firms. Thus, the impact of earnings management decreases, the greater the size of the firm. Again, we observe a positive and significant relationship at $1 \%$ level between leverage (LEV) and our proxies for earnings management because DeFond and Jiambalvo (1994) indicate that managers manipulate reported earnings upwards to meet debt covenants or contracts. Also, we find a positive association between LOSS and our proxies for earnings management consistent with prior research. For example, Francis and Yu (2009) observe that firms that made a loss in the previous years are more likely to manage earnings upwards in the current year and those with profits in the previous years have the tendency to manipulate profits downwards.

The remaining firm-level control variables exhibit their expected sign and significant levels. For example, NOA is positively (at $1 \%$ significant level) related ABNOR_ACCRUALS, ABNOR_CORE and REALMGMT2 but positively related to REALMGMT1 at $10 \%$ significant level. Additionally, BIG4 and TENURE show a weak negative relationship with ABNOR_ACCRUALS and ABNOR_CORE suggesting that religious managers decrease accruals earnings management where external monitoring from BIG4 is high but have the tendency to increase or decrease real activities manipulation due to limited scrutiny from 
auditors and regulators. The remaining firm-level and demographic control variables maintain their expected sign and level of significance.

\subsection{Impact in High and Low Religious Areas}

The above results and analyses have provided a clear evidence that religiosity of the firm's environment influences earnings management practices positively or negatively. However, the analyses do not reveal the extent to which the level (high or low) of religiosity in an area will affect earnings management practices. We test this by empirically breaking down the datasets into two samples, comprising of high and low religious areas and define areas with above (below) the median religiosity figure of $52 \%$ in our sample as having high (low) religiosity respectively. We expect that a highly religious environment will influence earnings management practices more significantly than areas with low religiosity figures ${ }^{14}$.

Table 5 below, presents the results of the analysis of high and low religious areas on firm managers' method of earnings management. Four proxies for earnings management are used to run separate regressions. Interestingly, we observe a strong positive or negative association at $1 \%$ significant level $(\mathrm{P}<0.01)$ between religiosity and all methods of earnings management in high religiosity areas. At the high religiosity areas, inferences still remain the same. Thus, religiosity is negative and significant for accrual-based earnings manipulation but positive and significant for both real- activities and classification shifting earnings management. Not surprisingly, the study notes that the association between religiosity at the low areas and earnings management methods is positively or negatively weak at $10 \%$ significance level. This suggests and reinforces the findings that religious social norms has influence on earnings management, and that the effect is acute especially in a highly religious environment.

\footnotetext{
${ }^{14}$ We break our sample into high and low religiosity reas because prior studies (McGuire et al., 2012; Callen et al., 2011; Dyreng et al., 2009) indicate that a highly religious environment has significant influence on attitudes and behaviour of the people living in that environment.
} 
TABLE 5: High Religiosity Areas versus Low Religiosity Areas

\begin{tabular}{|c|c|c|c|c|c|c|c|c|}
\hline \multirow[t]{2}{*}{ Variables } & \multicolumn{2}{|c|}{ ABNOR_ACC } & \multicolumn{2}{|c|}{ REALMGMT1 } & \multicolumn{2}{|c|}{ REALMGMT2 } & \multicolumn{2}{|c|}{ ABNOR_CORE } \\
\hline & HIGH & LOW & HIGH & LOW & HIGH & LOW & HIGH & LOW \\
\hline CONSTANT & $0.518 * * *$ & $0.061 * * *$ & $0.335 * *$ & $0.116^{*}$ & $0.180^{* *}$ & $0.080 * *$ & $0.340 * *$ & $0.022 *$ \\
\hline & $-0.068 * * *$ & $-0.043^{*}$ & $0.269 * * *$ & $0.132 *$ & $0.080 * * *$ & $0.056^{*}$ & $0.325 * * *$ & $0.010 *$ \\
\hline KEL & $(-4.133)$ & $(-1.760)$ & $(4.480)$ & (1.774) & $(3.670)$ & $(1.750)$ & $(4.067)$ & (1.802) \\
\hline SIZE & $\begin{array}{c}-0.051 * * * \\
(-5.780)\end{array}$ & $\begin{array}{l}-0.024 * * \\
(-2.280)\end{array}$ & $\begin{array}{l}-0.514 * * \\
(-8.760)\end{array}$ & $\begin{array}{c}-0.102 \\
(-1.010)\end{array}$ & $\begin{array}{c}0.524 * * * \\
(9.490)\end{array}$ & $\begin{array}{l}0.183^{*} \\
(1.900)\end{array}$ & $\begin{array}{c}-0.023 * * * \\
(-3.450)\end{array}$ & $\begin{array}{c}-0.040 * * \\
(2.040)\end{array}$ \\
\hline & $-0.005^{*}$ & -0.001 & -0.013 & -0.026 & $-0.035^{*}$ & -0.028 & -0.003 & -0.003 \\
\hline ANALYST_FOL & $(-1.730)$ & $(-0.140)$ & $(-0.640)$ & $(-0.890)$ & $(-1.800)$ & $(-1.020)$ & $(-0.970)$ & $(-0.590)$ \\
\hline ROA & $\begin{array}{c}-0.091 * * * \\
(-5.765)\end{array}$ & $\begin{array}{c}-0.015 * * * \\
(-2.610)\end{array}$ & $\begin{array}{c}-0.317 * * * \\
(-6.020)\end{array}$ & $\begin{array}{l}-0.81 * * \\
(-2.160)\end{array}$ & $\begin{array}{c}-0.079 * * \\
(-4.620)\end{array}$ & $\begin{array}{c}-0.049 * * \\
(-3.790)\end{array}$ & $\begin{array}{c}-0.553 * * * \\
(-8.490)\end{array}$ & $\begin{array}{c}-0.439 * * * \\
(-3.250)\end{array}$ \\
\hline LEV & $\begin{array}{l}0.12 * * * \\
(4.920)\end{array}$ & $\begin{array}{l}0.045^{*} \\
(1.870)\end{array}$ & $\begin{array}{c}0.360 * * \\
(2.250)\end{array}$ & $\begin{array}{c}0.060 \\
(0.210)\end{array}$ & $\begin{array}{c}0.185 \\
(1.220)\end{array}$ & $\begin{array}{c}0.200 \\
(0.740)\end{array}$ & $\begin{array}{l}0.088 * * * \\
(3.250)\end{array}$ & $\begin{array}{l}0.080 * \\
(1.740)\end{array}$ \\
\hline BIG4 & $\begin{array}{c}-0.005 \\
(-0.360)\end{array}$ & $\begin{array}{c}-0.016 \\
(-0.790)\end{array}$ & $\begin{array}{c}-0.114 \\
(-1.380)\end{array}$ & $\begin{array}{c}-0.111 \\
(-1.060)\end{array}$ & $\begin{array}{c}-0.093 \\
(-1.160)\end{array}$ & $\begin{array}{c}-0.127 \\
(-1.230)\end{array}$ & $\begin{array}{c}-0.002 \\
(-0.120)\end{array}$ & $\begin{array}{c}-0.029 \\
(-1.390)\end{array}$ \\
\hline MBV & $\begin{array}{c}0.015 * * * \\
(5.710)\end{array}$ & $\begin{array}{c}0.013 * * * \\
(2.660)\end{array}$ & $\begin{array}{c}0.160 * * * \\
(9.300)\end{array}$ & $\begin{array}{l}0.118^{* *} \\
(2.270)\end{array}$ & $\begin{array}{c}0.121^{* * *} \\
(7.450)\end{array}$ & $\begin{array}{c}0.058^{* *} \\
(2.270)\end{array}$ & $\begin{array}{c}0.036 * * * \\
(12.290)\end{array}$ & $\begin{array}{c}0.037 * * \\
(2.180)\end{array}$ \\
\hline LOSS & $\begin{array}{c}0.011 * * \\
(1.980)\end{array}$ & $\begin{array}{c}0.009 \\
(0.990)\end{array}$ & $\begin{array}{c}0.039 \\
(1.070)\end{array}$ & $\begin{array}{c}0.008 \\
(0.160)\end{array}$ & $\begin{array}{c}0.046 \\
(1.340)\end{array}$ & $\begin{array}{c}0.050 \\
(1.030)\end{array}$ & $\begin{array}{c}0.046 * * * \\
(4.630)\end{array}$ & $\begin{array}{c}0.015 * * \\
(2.370)\end{array}$ \\
\hline OPERA_RISK & $\begin{array}{c}0.014 * * * \\
(5.420)\end{array}$ & $\begin{array}{c}0.013 * * * \\
(2.660)\end{array}$ & $\begin{array}{c}0.054 * * * \\
(3.190)\end{array}$ & $\begin{array}{c}0.028 \\
(1.080)\end{array}$ & $\begin{array}{c}0.055 * * * \\
(3.380)\end{array}$ & $\begin{array}{l}0.050^{*} \\
(1.980)\end{array}$ & $\begin{array}{c}0.006^{* *} \\
(2.130)\end{array}$ & $\begin{array}{c}0.001 \\
(0.180)\end{array}$ \\
\hline BENCHMARK & $\begin{array}{c}0.045 \\
(0.760)\end{array}$ & $\begin{array}{c}0.016 \\
(0.120)\end{array}$ & $\begin{array}{c}-0.930 * * \\
(-2.340)\end{array}$ & $\begin{array}{c}-0.988 \\
(-1.380)\end{array}$ & $\begin{array}{c}-0.982 * * * \\
(-2.620)\end{array}$ & $\begin{array}{c}-0.409 \\
(-0.610)\end{array}$ & $\begin{array}{c}-0.157 * * \\
(-2.340)\end{array}$ & $\begin{array}{c}-0.102 \\
(-0.750)\end{array}$ \\
\hline TENURE & $\begin{array}{c}-0.002 \\
(-0.520)\end{array}$ & $\begin{array}{c}-0.006 \\
(-1.060)\end{array}$ & $\begin{array}{c}-0.016 \\
(-0.730)\end{array}$ & $\begin{array}{c}-0.037 \\
(-1.200)\end{array}$ & $\begin{array}{c}-0.008 \\
(-0.400)\end{array}$ & $\begin{array}{c}-0.034 \\
(-1.140)\end{array}$ & $\begin{array}{c}-0.003 \\
(-0.730)\end{array}$ & $\begin{array}{c}-0.004 \\
(-0.660)\end{array}$ \\
\hline CHANGE_GDP & $\begin{array}{c}-0.001 \\
(-0.840)\end{array}$ & $\begin{array}{c}-0.002 \\
(-0.790)\end{array}$ & $\begin{array}{c}-0.007 \\
(-0.940)\end{array}$ & $\begin{array}{c}-0.016 \\
(-1.530)\end{array}$ & $\begin{array}{c}-0.004 \\
(-0.650)\end{array}$ & $\begin{array}{c}-0.011 \\
(-1.160)\end{array}$ & $\begin{array}{c}-0.001 \\
(-0.520)\end{array}$ & $\begin{array}{c}-0.001 \\
(-0.160)\end{array}$ \\
\hline INVESTMENT & $\begin{array}{c}-0.471 * * * \\
(-9.900)\end{array}$ & $\begin{array}{l}-0.268^{* * * *} \\
(-3.420)\end{array}$ & $\begin{array}{c}0.793 * * \\
(2.510)\end{array}$ & $\begin{array}{c}0.584 \\
(1.360)\end{array}$ & $\begin{array}{l}0.512 * \\
(1.720)\end{array}$ & $\begin{array}{c}0.825 \\
(0.220)\end{array}$ & $\begin{array}{c}0.528 * * * \\
(9.890)\end{array}$ & $\begin{array}{c}0.473 * * * \\
(5.630)\end{array}$ \\
\hline NOA & $\begin{array}{c}0.037 * * * \\
(4.770)\end{array}$ & $\begin{array}{c}0.018 \\
(1.250)\end{array}$ & $\begin{array}{c}0.021 * * * \\
(3.400)\end{array}$ & $\begin{array}{c}0.250 * * \\
(2.090)\end{array}$ & $\begin{array}{l}0.102 * * \\
(2.120)\end{array}$ & $\begin{array}{c}0.296 * * * \\
(3.820)\end{array}$ & $\begin{array}{c}0.020 * * * \\
(2.610)\end{array}$ & $\begin{array}{l}0.042 * \\
(1.980)\end{array}$ \\
\hline $\begin{array}{l}\text { Demo. Control } \\
\text { Variables } \\
\text { Industry Fixed }\end{array}$ & Yes & Yes & Yes & Yes & Yes & Yes & Yes & Yes \\
\hline Effects & Yes & Yes & Yes & Yes & Yes & Yes & Yes & Yes \\
\hline Observations & 5939 & 2666 & 5505 & 2461 & 5939 & 2666 & 5915 & 2658 \\
\hline Adj. R-square & 0.25 & 0.15 & 0.16 & 0.05 & 0.22 & 0.04 & 0.17 & 0.05 \\
\hline
\end{tabular}

Notes: We use *,**,*** in a two tailed test to respectively indicate statistical significance at 10 percent, 5 percent and 1 percent levels. Areas with above (below) the median religiosity figure of 52\% in our sample are classified as having high (low) religiosity respectively. We estimate Model 1, 2, 3, and 4 using fixed effects regression. We show co-efficient estimates above and t-statistics below in brackets. ABNOR_ACCRUALS = measure of abnormal accruals using the ModifiedJones model in equation 1; REALMGMT1 = calculated as the aggregate of abnormal discretionary expenditures $\left(A B N O R_{-} D E X P\right)$ and abnormal production costs $\left(A B N O R_{-} P C O S T\right)$; REALMGMT2 = calculated as the aggregate of abnormal discretionary expenditure $\left(A B N O R_{\_} D E X P\right)$ and abnormal cash flows $\left(A B N O R_{-} C A S H\right)$. The higher the value for REALMGMT1 and REALMGMT2, the higher the level of real earnings management; ABNOR_CORE or UNEXP_CE = computed as the difference between reported core earnings (REP_CE) and expected core earnings (NOR_CE) for each firm (McVay, 2006); All other variables are defined above and in the Appendix A.

\subsection{Religiosity in Rural and Urban Areas}

Furthermore, we disaggregate the sample into rural and urban areas. Prior studies observe that earnings quality is associated with firms in rural areas (McGuire et al. 2012; Ucran, 2007). This point is further strengthened when firms in rural areas are audited by the BIG4 
auditors and have strong internal controls (Bayley and Taylor, 2007; Dechow et al., 2010). To indicate that religious social norms have influence on firms located in urban areas and that our results are not solely due to the higher earnings quality of the firms located in rural areas, we break the sample into urban and rural areas. In line with Loughran and Schulz $(2005)^{15}$, we classify Metropolitan Statistical Area (MSA) in each county with over five million population as urban area and repeat the main test using the urban subsample, comprising of MSA areas within the county with an average population of over five million residents.

TABLE 6: Religiosity and Earnings Management in Urban Areas

\begin{tabular}{|c|c|c|c|c|}
\hline VARIABLE & ABNOR_ACC & RAELMGMT1 & REALMGMT2 & ABNOR_CORE \\
\hline \multirow[t]{2}{*}{ CONSTANT } & $0.368 * *$ & $0.157 * *$ & $0.131 * *$ & $0.160^{* *}$ \\
\hline & $-0.054 * *$ & $0.480 * * *$ & $0.092 * * *$ & $0.129 * *$ \\
\hline \multirow[t]{2}{*}{ REL } & $(-2.370)$ & $(2.810)$ & $(3.170)$ & $(2.110)$ \\
\hline & $0.057 * * *$ & $0.504 * * *$ & $0.513 * * *$ & $0.017^{*}$ \\
\hline \multirow[t]{2}{*}{ SIZE } & $(7.060)$ & $(9.150)$ & $(9.780)$ & $(1.920)$ \\
\hline & $-0.005^{*}$ & -0.031 & $-0.043 * *$ & 0.004 \\
\hline \multirow[t]{2}{*}{ ANALYST_FOL } & $(-1.670)$ & $(-1.640)$ & $(-2.440)$ & $(1.400)$ \\
\hline & $-0.075 * * *$ & $-0.075 * * *$ & $-0.156^{* * *}$ & $-0.582 * * *$ \\
\hline \multirow[t]{2}{*}{ ROA } & $(-8.920)$ & $(-6.510)$ & $(-5.380)$ & $(-8.470)$ \\
\hline & $0.118 * * *$ & 0.259 & 0.022 & $0.075 * * *$ \\
\hline \multirow[t]{2}{*}{ LEV } & $(4.870)$ & $(1.580)$ & $(0.140)$ & $(2.780)$ \\
\hline & $-0.020 *$ & -0.072 & 0.091 & 0.017 \\
\hline \multirow[t]{2}{*}{ BIG4 } & $(-1.660)$ & $(-0.930)$ & $(1.180)$ & $(1.290)$ \\
\hline & $0.013 * * *$ & $0.125 * * *$ & $0.084 * * *$ & $0.034 * * *$ \\
\hline \multirow[t]{2}{*}{ MBV } & $(5.150)$ & $(7.330)$ & $(5.240)$ & $(12.430)$ \\
\hline & 0.004 & $0.064 *$ & $0.075^{* *}$ & $0.025 * * *$ \\
\hline \multirow[t]{2}{*}{ LOSS } & $(0.770)$ & $(1.830)$ & $(2.250)$ & $(4.420)$ \\
\hline & $0.015 * * *$ & 0.025 & $0.028 *$ & $0.005^{*}$ \\
\hline \multirow[t]{2}{*}{ OPERA_RISK } & $(5.780)$ & $(1.500)$ & $(1.720)$ & $(1.690)$ \\
\hline & 0.047 & $0.878 * *$ & $-0.736^{*}$ & $-0.120 *$ \\
\hline \multirow[t]{2}{*}{ BENCHMARK } & $(0.740)$ & $(-2.020)$ & $(-1.790)$ & $(-1.700)$ \\
\hline & -0.002 & -0.021 & -0.017 & -0.002 \\
\hline \multirow[t]{2}{*}{ TENURE } & $(-0.560)$ & $(-0.960)$ & $(-0.850)$ & $(-0.540)$ \\
\hline & -0.001 & $-0.013 *$ & -0.007 & -0.001 \\
\hline \multirow[t]{2}{*}{ CHANGE_GDP } & $(-0.040)$ & $(-1.760)$ & $(-0.990)$ & $(-0.700)$ \\
\hline & $-0.392 * * *$ & 0.194 & 0.169 & $0.542 * * *$ \\
\hline \multirow[t]{2}{*}{ INVESTMENT } & $(-8.570)$ & $(0.620)$ & $(0.570)$ & $(10.700)$ \\
\hline & $0.002 * * *$ & $0.165 * * *$ & $0.223 * * *$ & $0.031 * * *$ \\
\hline NOA & $(2.970)$ & $(3.380)$ & $(4.760)$ & $(3.870)$ \\
\hline $\begin{array}{l}\text { Demographic Cont. } \\
\text { Variables }\end{array}$ & Yes & Yes & Yes & Yes \\
\hline $\begin{array}{l}\text { Industry Fixed } \\
\text { Effects }\end{array}$ & Yes & Yes & Yes & Yes \\
\hline Observations & 6612 & 6111 & 6612 & 6586 \\
\hline $\begin{array}{l}\text { Adj. R-square } \\
\text { (overall) }\end{array}$ & 0.19 & 0.07 & 0.13 & 0.18 \\
\hline
\end{tabular}

\footnotetext{
${ }^{15}$ Loughran and Schulz (2005) define urban areas as the most-populated areas with an average of over five million residents in the MSA within the county. We replicate our analysis based on their definition and find that the inferences remain the same.
} 


\begin{abstract}
Notes: We use $*, * *, * * *$ in a two tailed test to respectively indicate statistical significance at 10 percent, 5 percent and 1 percent levels; we use a sub-sample of firms in urban areas classified as MSA in each county with over five million population in line with Loughran and Schulz (2005); we estimate Model 1, 2, 3, and 4 using fixed effects regression; we show co-efficient estimates above and t-statistics below in brackets. ABNOR_ACCRUALS = measure of abnormal accruals using the Modified-Jones model in equation 1; REALMGMT1 = calculated as the aggregate of abnormal discretionary expenditures (ABNOR_DEXP) and abnormal production costs $\left(A B N O R_{-} P C O S T\right)$; REALMGMT2 = calculated as the aggregate of abnormal discretionary expenditure $\left(A B N O R \_D E X P\right)$ and abnormal cash flows $\left(A B N O R \_C A S H\right)$. The higher the value for REALMGMT1 and REALMGMT2, the higher the level of real earnings management; ABNOR_CORE or UNEXP_CE = computed as the difference between reported core earnings (REP_CE) and expected core earnings (NOR_CE) for each firm (McVay, 2006); All other variables are defined above and in the Appendix A.
\end{abstract}

Table 6 above, presents the results of the analysis of the relationship between religiosity and earnings management for firms located in urban areas of all U.S. counties. Indeed, the conclusions remain the same using only the urban area subsample. We find that religiosity is negatively and significantly (at 5\% level) associated with accrual-based earnings management but positively and significantly (at $1 \%$ level) associated with both real activities and classification shifting earnings management. This suggests that the findings in respect of the association between religious social norms and earnings management methods are not solely influenced by the earnings quality associated with rural and urban areas. The findings are robust and clearly demonstrate that religiosity of urban firms' environment impacts positively and negatively on the earnings management practices in the U.S.

\title{
5.4 Religiosity and Corporate Governance
}

Recently, Zalata and Roberts (2015) find that classification shifting is less common in firms with more independent directors and directors with long tenure but negative association exists between audit committees, large board size, CEOs with long tenure and classification shifting. Indeed, literature review shows that a firm's corporate governance mechanism affects earnings management practices (Hossain et al. 2011, Lin and Hwang, 2010; Harris and Raviv, 2008). Therefore, we interact religiosity with corporate governance variables to assess their impact on earnings management.

Table 7 presents the association between religiosity, corporate governance variables and earnings management. 
TABLE 7: Religiosity with Corporate Governance Variables

\begin{tabular}{|c|c|c|c|c|}
\hline VARIABLE & ABNOR_ACC & RAELMGMT1 & REALMGMT2 & ABNOR_CORE \\
\hline CONSTANT & $0.538 * * *$ & $0.479 * *$ & $0.422 * *$ & $0.490 * * *$ \\
\hline \multirow{2}{*}{ REL } & $-0.084 * * *$ & $0.259 * *$ & $0.040 * *$ & $0.042 * * *$ \\
\hline & $(-5.260)$ & $(2.408)$ & $(2.390)$ & $(2.640)$ \\
\hline \multirow{2}{*}{ BODSIZE } & $-0.031 * * *$ & $-0.024 * *$ & $-0.094 * *$ & $-0.099 * *$ \\
\hline & $(-2.120)$ & $(-2.230)$ & $(-2.020)$ & $(-2.310)$ \\
\hline \multirow{2}{*}{ BODIND } & $-0.293 * * *$ & $-0.097 * *$ & $-0.086 * *$ & $-0.017 * * *$ \\
\hline & $(-2.703)$ & $(-2.420)$ & $(-2.190)$ & $(-2.720)$ \\
\hline \multirow{2}{*}{ AUCOM } & $-0.017 * *$ & $-0.042 * *$ & -0.068 & -0.017 \\
\hline & $(-2.420)$ & $(-2.030)$ & $(-1.449)$ & $(-0.510)$ \\
\hline \multirow{2}{*}{ CEOTEN } & 0.294 & 0.047 & $0.077 * *$ & 0.074 \\
\hline & $(1.350)$ & $(1.190)$ & $(2.040)$ & $(1.120)$ \\
\hline \multirow{2}{*}{ RELBODSIZE } & $-0.135 * * *$ & $-0.054 * *$ & $-0.088 * *$ & $-0.025 * *$ \\
\hline & $(-3.270)$ & $(-2.130)$ & $(-2.009)$ & $(-2.300)$ \\
\hline \multirow{2}{*}{ RELBODIND } & $-0.076 * * *$ & $-0.087 * *$ & $-0.016 * *$ & $-0.057 * * *$ \\
\hline & $(-3.868)$ & $(-2.090)$ & $(-1.980)$ & $(-2.710)$ \\
\hline \multirow{2}{*}{ RELAUCOM } & $-0.275 * * *$ & $-0.066 * *$ & -0.075 & -0.036 \\
\hline & $(-3.346)$ & $(-2.040)$ & $(-1.580)$ & $(-0.590)$ \\
\hline \multirow{2}{*}{ RELCEOTEN } & $0.075^{* *}$ & 0.013 & $0.020 * *$ & 0.019 \\
\hline & $(2.360)$ & $(1.220)$ & $(2.040)$ & $(1.090)$ \\
\hline \multirow{2}{*}{ SIZE } & $-0.034 * *$ & $0.055^{* * *}$ & $0.055^{* * *}$ & -0.008 \\
\hline & $(-2.190)$ & $(3.660)$ & $(3.500)$ & $(-1.040)$ \\
\hline \multirow{2}{*}{ ANALYST_FOL } & -0.066 & -0.013 & -0.024 & -0.002 \\
\hline & $(-1.480)$ & $(-0.810)$ & $(-1.570)$ & $(-0.740)$ \\
\hline \multirow{2}{*}{ ROA } & $-0.004 * * *$ & $-0.095 * * *$ & $-0.039 * * *$ & $-0.061 * * *$ \\
\hline & $(-4.690)$ & $(-8.360)$ & $(-7.180)$ & $(-9.640)$ \\
\hline \multirow{2}{*}{ LEV } & 0.170 & 0.252 & 0.058 & $0.075^{* * *}$ \\
\hline & $(1.350)$ & $(1.550)$ & $(0.440)$ & $(3.280)$ \\
\hline \multirow{2}{*}{ MBV } & 0.093 & 0.252 & $0.396^{*}$ & 0.036 \\
\hline & $(1.550)$ & $(1.110)$ & (1.920) & (1.090) \\
\hline \multirow{2}{*}{ LOSS } & $0.013 * * *$ & $0.053 * *$ & $0.099 * * *$ & $0.027 * * *$ \\
\hline & $(2.600)$ & $(2.470)$ & $(3.360)$ & $(5.480)$ \\
\hline \multirow{2}{*}{ OPERA_RISK } & $0.005 * *$ & 0.039 & $0.073 * * *$ & $0.005^{*}$ \\
\hline & $(2.170)$ & $(1.600)$ & $(2.590)$ & $(1.940)$ \\
\hline \multirow{2}{*}{ BENCHMARK } & 0.014 & -0.637 & 0.042 & 0.099 \\
\hline & $(1.480)$ & $(-1.630)$ & $(1.070)$ & $(1.650)$ \\
\hline \multirow{2}{*}{ CHANGE_GDP } & 0.035 & -0.012 & -0.529 & -0.001 \\
\hline & $(0.640)$ & $(-0.960)$ & $(-1.550)$ & $(-0.940)$ \\
\hline \multirow{2}{*}{ INVESTMENT } & -0.004 & 0.485 & 0.002 & 0.468 \\
\hline & $(-0.420)$ & $(0.890)$ & $(0.120)$ & $(0.940)$ \\
\hline \multirow{2}{*}{ NOA } & $0.377^{*}$ & $0.108 * * *$ & 0.008 & $0.030 * * *$ \\
\hline & $(1.820)$ & $(2.620)$ & $(1.320)$ & $(4.310)$ \\
\hline Demographic Control & Yes & Yes & Yes & Yes \\
\hline \multicolumn{5}{|l|}{ Variables } \\
\hline Industry Fixed Effects & Yes & Yes & Yes & Yes \\
\hline Observations & 8605 & 7966 & 8,605 & 8,573 \\
\hline R-square (overall) & 0.29 & 0.08 & 0.13 & 0.21 \\
\hline
\end{tabular}

Notes: we use $*, * *, * * *$ in a two tailed test to respectively indicate statistical significance at 10 percent, 5 percent and 1 percent levels; we estimate Model 1,2, 3, and 4 using fixed effects regression; we show co-efficient estimates above and tstatistics below in brackets. ABNOR_ACCRUALS = measure of abnormal accruals using the Modified-Jones model in equation 1; REALMGMT1 = calculated as the aggregate of abnormal discretionary expenditures $\left(A B N O R \_D E X P\right)$ and abnormal production costs $\left(A B N O R \_P C O S T\right)$; REALMGMT2 = calculated as the aggregate of abnormal discretionary expenditure $\left(A B N O R_{-} D E X P\right)$ and abnormal cash flows $\left(A B N O R_{-} C A S H\right)$. The higher the value for REALMGMT1 and REALMGMT2, the higher the level of real earnings management (Cohen and Zarowin, 2010); ABNOR_CORE or 
UNEXP_CE $=$ computed as the difference between reported core earnings (REP_CE) and expected core earnings (NOR_CE) for each firm (McVay, 2006); BODSIZE = total number of directors on the board; BODIND = calculated as the number of independent directors divided by the total number of directors on the board; AUCOM = a dummy variable coded as 1 if the company has an audit committee, otherwise zero; CEOTEN = measured as the number of years a CEO has held the position as CEO in the firm; RELBODSIZE = religiosity multiplied by board size; RELBODIND = religiosity multiplied by board independence; RELAUCOM = religiosity multiplied by audit committee; RELCEOTEN = religiosity multiplied by CEO turnover; All other variables are defined above and in the Appendix A.

We find a significantly negative relationship (at $1 \%$ level, $\mathrm{p}$-value $=0.000$ ) between religiosity and accrual-based earnings management, at 5\% significant level between religiosity, board size and audit committee but $10 \%$ negative association between board independence and accrual-based earnings management. However, the relationship between CEO tenure and accrual-based earnings management was negatively insignificant. The firm level and demographic control variables maintain their expected signs and coefficients. Clearly, results in table 7 indicate that religiosity influences earnings management practices despite the inclusion of corporate governance variables. However, the coefficient and t-values change from -0.059 and -3.406 to -0.084 and -5.260 respectively. This suggests that both religiosity and corporate governance variables play a complementary role in mitigating accruals-based earnings management in column 2. Therefore, our initial results are supported that there is a significantly negative association between religious social norms and accrualsbased earnings management. Our study report that firms with high religious social norms coupled with good corporate governance mitigate accrual earnings management and the converse is true.

Again, inferences remain the same for real activities and classification shifting earnings management. In table 7 columns 3 and 4 , there is a significantly $(\mathrm{P}<0.05)$ positive association between religiosity and both measures of real activities management. The coefficient and t-values without governance variables for REALMGMT2 reduced from 0.049 to 0.040 and 3.396 to 2.390 respectively. Even though corporate governance mitigates earnings management, with real-activities and classification shifting, the impact becomes relatively less pronounced.

Interestingly, in column 5, we find that the association between classification shifting and religious social norms is still positively significant at $1 \%(\mathrm{p}<0.001)$. Thus with or without corporate governance variables, the results and conclusion remain the same. Thus even with 
good corporate governance, religious social norms still impact positively on real activities and classification shifting earnings management at 5\% and $1 \%$ level of significance respectively. Therefore, the results suggest that the lack of both internal and external monitoring (from auditors and regulators) coupled with the fact that there is no GAAP violation when firms engage in both real-activities and classification shifting facilitates these methods of earnings management. This finding is consistent with prior research which indicate that the presence of BIG4 and regulators do not mitigate real activities-based earnings management (McGuire et al. 2012). We contribute to existing few studies that religious social norms impact positively and significantly on classification shifting and this association is even the same when the firm has good corporate governance mechanism in place.

In addition, we observe a negative association between the governance variables (BODSIZE, BODIND and AUCOM) and measures of real earnings management at $5 \%(\mathrm{p}<0.05)$ but a positively (significant or insignificant) association between CEOTEN and methods of earnings management, suggesting that CEOs with long tenure wield substantial influence and power to influence earnings management outcome to boost reported earnings. Again, we find that the results for RELBODSIZE; RELBODIND and RELAUCOM show a significantly negative association at $1 \%$ or $5 \%$ between RELBODSIZE; RELBODIND, RELAUCOM and the methods of earnings management. Even though the relationship is negative, RELAUCOM is insignificant for classification shifting. This finding is consistent with prior studies (Zalata and Roberts, 2015; Hossain et al. 2011) and indicates that effective corporate governance mechanism in an organisation has negative impact on earnings management practices. Notwithstanding, the results show that religiosity of the firms' environment has the potential to shape the attitudes and behaviour of firms' managers even when there is a good corporate governance mechanism in operation. On the other hand, the results demonstrate that the influence of religious social norms serves as other form of monitoring for stakeholders and complement the existing governance mechanism instituted by management in curbing accruals earnings management within a firm (Ayers, Ramalingegowda and Yeung, 2011; Burns, Kedia and Lipson, 2010). However, even with good corporate governance mechanism in place, earnings management through real activities and classification shifting is 
pervasive and significant in an environment where religious social norms influences managerial behaviour and decisions.

\section{Association between Religiosity and Alternative measures of Earnings Management}

We also conduct further robustness tests to support the results using alternative measures of earnings management.

\subsection{Validity of McVay's (2006) Model}

We use Fan et al (2010) model which excludes contemporaneous accruals from McVay's (2006) model to avoid potential bias. We estimate the results for both McVay (2006) model and Fan et al (2010) model as shown in Table 8 below. Even though, we drop contemporaneous accruals from the McVay's model, unexpected core earnings are still positively related to special items, which is an evidence of classification shifting. The inferences remain the same as the coefficients and significance levels of Fan et al (2010) model are analogous to those observe under the McVay's (2006) model. Again, the firm level and demographic control variables maintain their expected signs and coefficients. In both models, we find that religiosity is positive and significantly $(\mathrm{P}<0.001)$ associated with classification shifting. This means that the results in Table 8, column 2 without current year accruals in Fan et al (2010) model is a clear confirmation that our initial findings of misclassification of core expenses into special items rooted in McVay's (2006) expectation model is not determined by model bias.

Furthermore, we surrogate total accruals by working capital accruals in both McVay's (2006) and Fan et al (2010) expectation models. Athanasakou et al. (2009) observe that the substitution of working capital accruals is important because total accruals in the McVay's (2006) model comprise of depreciation expenses and special items accruals which are likely to introduce bias into the expectation model. Therefore, we re-estimate the regression results and find that the coefficients and significant levels are similar to the initial results. 
TABLE 8: Religiosity and Classification Shifting

\begin{tabular}{|c|c|c|}
\hline VARIABLE & $\begin{array}{c}\text { McVay (2006) } \\
\text { Model } \\
\end{array}$ & $\begin{array}{c}\text { Fan et al (2010) } \\
\text { Model }\end{array}$ \\
\hline Constant & $0.560 * * *$ & $0.483 * * *$ \\
\hline REL & $\begin{array}{l}0.095 * * * \\
(2.850)\end{array}$ & $\begin{array}{l}0.098 * * * \\
(3.150)\end{array}$ \\
\hline SIZE & $\begin{array}{l}-0.024 * * \\
(-3.102)\end{array}$ & $\begin{array}{l}-0.022 * * \\
(-2.330)\end{array}$ \\
\hline ANALYST_FOL & $\begin{array}{l}-0.002 \\
(-0.640)\end{array}$ & $\begin{array}{r}-0.004 \\
(-1.300)\end{array}$ \\
\hline ROA & $\begin{array}{l}-0.563 * * * \\
(-9.670)\end{array}$ & $\begin{array}{l}-0.126 * * * \\
(-8.750)\end{array}$ \\
\hline LEV & $\begin{array}{l}0.074 * * * \\
(3.250)\end{array}$ & $\begin{array}{l}0.022 * * * \\
(3.380)\end{array}$ \\
\hline BIG4 & $\begin{array}{l}-0.020^{*} \\
(-1.800)\end{array}$ & $\begin{array}{l}-0.023 \\
(-1.630)\end{array}$ \\
\hline MBV & $\begin{array}{l}0.036 * * * \\
(3.194)\end{array}$ & $\begin{array}{l}0.058 * * * \\
(4.370)\end{array}$ \\
\hline LOSS & $\begin{array}{l}0.027 * * * \\
(5.470)\end{array}$ & $\begin{array}{l}0.006 * * * \\
(4.080)\end{array}$ \\
\hline OPERA_RISK & $\begin{array}{c}0.005 * * \\
(2.030)\end{array}$ & $\begin{array}{c}0.117 \\
(1.610)\end{array}$ \\
\hline RURAL & $\begin{array}{c}-0.005 \\
(-1.400)\end{array}$ & $\begin{array}{c}-0.003 \\
(-0.790)\end{array}$ \\
\hline BENCHMARK & $\begin{array}{c}0.102 \\
(1.600)\end{array}$ & $\begin{array}{c}0.002 \\
(0.970)\end{array}$ \\
\hline TENURE & $\begin{array}{c}-0.000 \\
(-0.170)\end{array}$ & $\begin{array}{c}-0.102 \\
(-0.620)\end{array}$ \\
\hline CHANGE_GDP & $\begin{array}{c}-0.001 \\
(-0.950)\end{array}$ & $\begin{array}{c}-0.056 \\
(-0.620)\end{array}$ \\
\hline INVESTMENT & $\begin{array}{l}0.466 * * \\
(2.100)\end{array}$ & $\begin{array}{c}0.024^{*} \\
(1.730)\end{array}$ \\
\hline NOA & $\begin{array}{l}0.030 * * \\
(2.380)\end{array}$ & $\begin{array}{l}0.004 * * \\
(2.300)\end{array}$ \\
\hline Demographic Control Variables & Yes & Yes \\
\hline Industry Fixed Effects & Yes & Yes \\
\hline Observations & 8,573 & 8,573 \\
\hline Adjusted R-square (overall) & 0.26 & 0.23 \\
\hline
\end{tabular}

Notes: We use $*, * *, * * *$ in a two tailed test to respectively indicate statistical significance at 10 percent, 5 percent and 1 percent levels; we estimate McVay (2006) and Fan et al. (2010) models using fixed effects regression ${ }^{16}$; we show coefficient estimates above and t-statistics below in brackets; All other variables are defined above and in the Appendix A.

\subsection{Alternative Measures of Real Activities Earnings Management and Religiosity}

Further sensitivity analyses are also conducted using individual measures of real activities earnings management. Specifically, abnormal production costs, (ABNOR_PCOST); abnormal discretionary expenses (ABNOR_DEXP) and abnormal cash flows

\footnotetext{
${ }^{16}$ In McVay's (2006) model, ABNOR_CORE or UNEXP_CE is computed using total accruals but Fan et al. (2010) model excludes contemporaneous accruals from the McVay's model to avoid potential model bias;
} 
(ABNOR_CASFO) are used as dependent variables and proxies for real activities based earnings management. Cohen and Zarowin (2010) observe that aggregating these three individual variables to compute REALMGMT1 and REALMGMT2 might influence earnings and weaken the results. Table 9 below provides results for aggregated and individual measures of real-activities based earnings management.

TABLE 9: Religiosity and Real Activities Measures

\begin{tabular}{|c|c|c|c|c|c|}
\hline VARIABLE & $\begin{array}{c}\text { RAELMGM } \\
\text { T1 }\end{array}$ & $\begin{array}{l}\text { REALMGMT } \\
2\end{array}$ & $\begin{array}{l}\text { ABNOR_- } \\
\text { PCOST }\end{array}$ & $\begin{array}{l}\text { ABNOR_- } \\
\text { DEXP }\end{array}$ & $\begin{array}{l}\text { ABNOR_- } \\
\text { CASFO }\end{array}$ \\
\hline CONSTANT & $0.679 * * *$ & $0.571 * *$ & $0.242 * *$ & $0.257 * *$ & $0.050 * *$ \\
\hline REL & $\begin{array}{l}0.348 * * * \\
(3.240)\end{array}$ & $\begin{array}{l}0.049 * * * \\
(3.396)\end{array}$ & $\begin{array}{l}0.106 * * * \\
(2.680)\end{array}$ & $\begin{array}{l}0.240 * * * \\
(3.200)\end{array}$ & $\begin{array}{r}0.157 * * * \\
(2.580)\end{array}$ \\
\hline SIZE & $\begin{array}{l}-0.544 * * * \\
(-11.660)\end{array}$ & $\begin{array}{l}-0.556 * * * \\
(-12.540)\end{array}$ & $\begin{array}{l}-0.110 * * * \\
(-3.500)\end{array}$ & $\begin{array}{l}-0.072 * * * \\
(-5.050)\end{array}$ & $\begin{array}{l}-0.182 * * * \\
(-8.090)\end{array}$ \\
\hline ANALYST_FOL & $\begin{array}{c}-0.012 \\
(-0.770)\end{array}$ & $\begin{array}{c}-0.023 \\
(-1.580)\end{array}$ & $\begin{array}{l}-0.023 * * \\
(-2.100)\end{array}$ & $\begin{array}{l}-0.036 * * \\
(-2.220)\end{array}$ & $\begin{array}{c}-0.017 * * \\
(-2.280)\end{array}$ \\
\hline ROA & $\begin{array}{l}-0.951 * * * \\
(-3.141)\end{array}$ & $\begin{array}{c}-0.395^{* * *} * \\
(-3.029)\end{array}$ & $\begin{array}{l}-0.029 * * * \\
(-3.470)\end{array}$ & $\begin{array}{l}-0.056 * * * \\
(-4.360)\end{array}$ & $\begin{array}{l}-0.030 * * * \\
(-3.620)\end{array}$ \\
\hline LEV & $\begin{array}{l}0.248^{*} \\
(1.820)\end{array}$ & $\begin{array}{c}0.055 \\
(0.430)\end{array}$ & $\begin{array}{l}0.045^{*} \\
(1.750)\end{array}$ & $\begin{array}{l}0.005 \\
(0.040)\end{array}$ & $\begin{array}{l}0.275 * * * \\
(4.190)\end{array}$ \\
\hline BIG4 & $\begin{array}{l}-0.068 \\
(-1.040)\end{array}$ & $\begin{array}{l}-0.059 \\
(-0.920)\end{array}$ & $\begin{array}{l}-0.100 \\
(-0.230)\end{array}$ & $\begin{array}{l}-0.107 \\
(-1.570)\end{array}$ & $\begin{array}{l}-0.011 \\
(-0.360)\end{array}$ \\
\hline MBV & $\begin{array}{l}-0.146^{* * *} \\
(-10.150)\end{array}$ & $\begin{array}{l}-0.100 * * * \\
(-7.400)\end{array}$ & $\begin{array}{l}-0.94 * * * \\
(-9.490)\end{array}$ & $\begin{array}{l}-0.051 * * * \\
(-3.530)\end{array}$ & $\begin{array}{l}-0.122 * * * \\
(-7.770)\end{array}$ \\
\hline LOSS & $\begin{array}{l}0.052 * \\
(1.760)\end{array}$ & $\begin{array}{l}0.073 * * \\
(2.580)\end{array}$ & $\begin{array}{l}0.014^{*} \\
(1.670)\end{array}$ & $\begin{array}{l}0.079 * * \\
(2.590)\end{array}$ & $\begin{array}{l}0.025^{*} \\
(1.770)\end{array}$ \\
\hline OPERA_RISK & $\begin{array}{l}0.037 * * * \\
(2.620)\end{array}$ & $\begin{array}{l}0.041 * * * \\
(2.990)\end{array}$ & $\begin{array}{l}0.015 * * \\
(2.470)\end{array}$ & $\begin{array}{c}0.008 \\
(1.540)\end{array}$ & $\begin{array}{l}0.031 * * * \\
(4.380)\end{array}$ \\
\hline RURAL & $\begin{array}{l}-0.024 \\
(-1.050)\end{array}$ & $\begin{array}{l}-0.015 \\
(-0.720)\end{array}$ & $\begin{array}{l}-0.021 \\
(-1.020)\end{array}$ & $\begin{array}{l}-0.010 \\
(-0.620)\end{array}$ & $\begin{array}{l}-0.012 \\
(-0.520)\end{array}$ \\
\hline BENCHMARK & $\begin{array}{l}-0.644^{*} \\
(-1.770)\end{array}$ & $\begin{array}{l}-0.532 \\
(-1.550)\end{array}$ & $\begin{array}{l}0.023 \\
(0.920)\end{array}$ & $\begin{array}{c}-.0775 * * \\
(-2.110)\end{array}$ & $\begin{array}{l}-0.028 \\
(-0.160)\end{array}$ \\
\hline TENURE & $\begin{array}{c}-0.009 \\
(-0.510)\end{array}$ & $\begin{array}{c}-0.002 \\
(-0.110)\end{array}$ & $\begin{array}{c}-0.001 \\
(-0.100)\end{array}$ & $\begin{array}{c}-0.026 \\
(-1.420)\end{array}$ & $\begin{array}{l}-0 . .001 \\
(-0.111)\end{array}$ \\
\hline CHANGE_GDP & $\begin{array}{l}-0.012 * \\
(-1.910)\end{array}$ & $\begin{array}{c}-0.007 \\
(-1.280)\end{array}$ & $\begin{array}{l}-0.011 * * * \\
(-2.590)\end{array}$ & $\begin{array}{c}-0.005 \\
(-0.740)\end{array}$ & $\begin{array}{c}-0.006^{* *} \\
(-2.060)\end{array}$ \\
\hline INVESTMENT & $\begin{array}{l}0.498 * \\
(1.940)\end{array}$ & $\begin{array}{c}0.147 \\
(0.600)\end{array}$ & $\begin{array}{l}0.077 * * \\
(1.960)\end{array}$ & $\begin{array}{l}0.840 * * * \\
(3.200)\end{array}$ & $\begin{array}{c}-0.097 * * * \\
(9.670)\end{array}$ \\
\hline NOA & $\begin{array}{l}0.106^{* *} \\
(2.580)\end{array}$ & $\begin{array}{l}0.169 * * * \\
(4.320)\end{array}$ & $\begin{array}{l}0.710 * * \\
(2.500)\end{array}$ & $\begin{array}{l}0.226 * * * \\
(5.370)\end{array}$ & $\begin{array}{c}0.012 \\
(1.590)\end{array}$ \\
\hline $\begin{array}{l}\text { Demographic Control } \\
\text { Variables }\end{array}$ & Yes & Yes & Yes & Yes & Yes \\
\hline Industry Fixed Effects & Yes & Yes & Yes & Yes & Yes \\
\hline Observations & 7,966 & 8,605 & 7966 & 8605 & 8605 \\
\hline R-square (overall) & 0.09 & 0.15 & 0.12 & 0.06 & 0.09 \\
\hline
\end{tabular}

Notes: We use $*, * *, * * *$ in a two tailed test to respectively indicate statistical significance at 10 percent, 5 percent and 1 percent levels; In Table 9, we show the results of both aggregated and individual measures of real earnings management, Cohen and Zarowin (2010). We estimate Model 1, 2, 3, 4 and 5 using fixed effects regression; we show co-efficient estimates above and t-statistics below in brackets. REALMGMT1 = calculated as the aggregate of abnormal discretionary expenditures (ABNOR_DEXP) and abnormal production costs (ABNOR_PCOST); Cohen and Zarowin (2010). 
REALMGMT2 $=$ calculated as the aggregate of abnormal discretionary expenditure $\left(A B N O R \_D E X P\right)$ and abnormal cash flows $\left(A B N O R_{-} C A S H\right)$. The higher the value for REALMGMT1 and REALMGMT2, the higher the level of real earnings management; Cohen and Zarowin (2010). ABNOR_DEXP = estimated by regressing discretionary expenses on the inverse of lagged total assets and lagged sales scaled by lagged total assets. The figure for (ABNOR_DEXP) is multiplied by negative one (-1), consequently, a higher (ABNOR_DEXP) figure represents higher real earnings management; ABNOR_PCOST = estimated by regressing PCOST on the inverse of lagged total assets, sales scaled by lagged total assets, change in sales scaled by lagged total assets. The figure for $\left(A B N O R_{-} P C O S T\right)$ is multiplied by negative one $(-1)$, consequently, a higher (ABNOR_PCOST) figure represents higher real earnings management. ABNOR_CASH $=$ estimated by regressing CASFO scaled by lagged total assets on the inverse of lagged total assets, sales scaled by lagged total assets, change in sales scaled by lagged total assets. The figure for (ABNOR_ CASH) is multiplied by negative one $(-1)$, consequently, a higher (ABNOR_CASH) figure represents higher real earnings management, Cohen and Zarowin (2010). Other variables are defined above and in the Appendix A.

The individual results of the association between religious social norms and abnormal production costs, abnormal discretionary expenses and abnormal cash flows are presented in columns 4 to 6 in Table 9. Similarly, columns 2 and 3 in table 9 show the aggregated results for the measures of real-activities earnings management previously reported in tables 4 . Interestingly, we find evidence of a significant $(\mathrm{P} \leq 0.001)$ positive association between religiosity and the three individual measures of real activities. The results are consistent with the aggregated measures of real-activities (REALMGMT1 and REALMGMT2), suggesting that because real-activities earnings management is not subject to scrutiny of auditors and does not violate GAAP, religious managers deem it appropriate to cut down advertising, R \& D expenses, delay payment of goods, reduce selling prices, give more discounts etc. to manage reported earnings upwards or downwards.

\subsection{Alternative Measures of Discretionary Accruals}

Again, we conduct further robustness test to estimate discretionary abnormal accruals using working capital accruals defined in equation (2). Following prior research (Behn, Gotti, Herrmann, and Kang, 2013; Dechow et al, 2012; Haw, Ho, and Li, 2011; Xie et al. 2003), we compute discretionary accruals using the modified-Jones model with working capital accruals for each firm year observation and two digit SIC code and industry. The results are presented in Table 10 below. The results support the earlier findings that the association between religiosity and abnormal accruals is still negative and significant $(\mathrm{p}<0.01)$ when discretionary accruals are computed using working capital accruals in the modified-Jones model. In additional untabulated analyses, we augment both Jones-model and modified-Jones model to include lagged return on assets (ROA). Prior studies (Dechow et al., 2012; Kothari et al, 2005) observe that inclusion of past ROA attenuates misspecification but does not eliminate it. Interestingly, in both Jones-model and modified-Jones model with lagged ROA, 
we find that the relationship between abnormal accruals and religiosity is significantly negative $(\mathrm{p}<0.01)$.

TABLE 10: Religiosity and Accrual Based Earnings Management

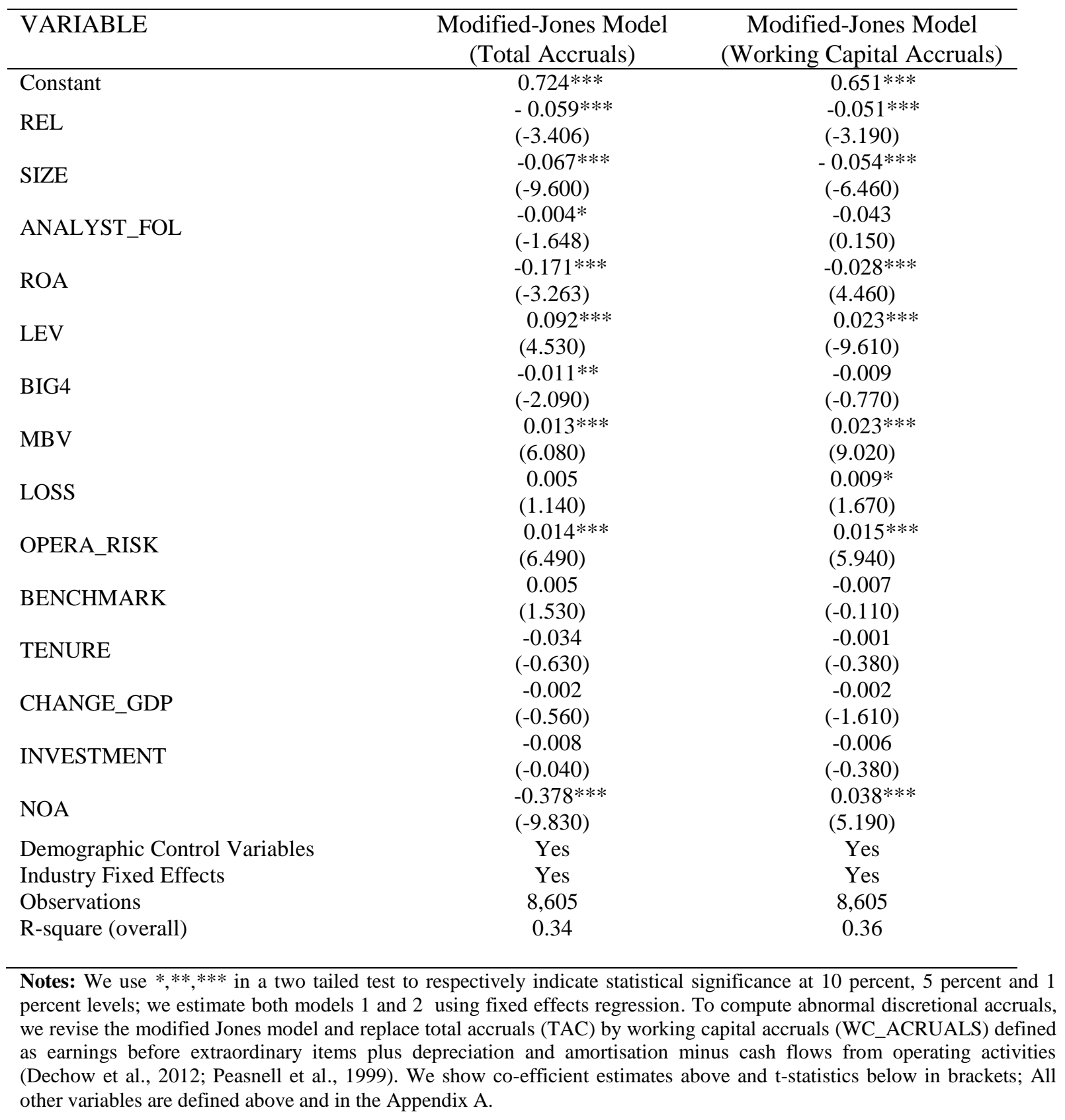

\subsection{Alternative Measure of Religiosity}

Although our measure of religious social norm is supported by prior studies (McGuire et al. 2012; Callen et al 2011; Grullon et al. 2010), we conduct further robustness tests to ensure 
that our results are free from potential bias and do not rely on generalisation of religious datasets across several years. We use different source of religious datasets collected by Gallup survey for the study period ${ }^{17}$. We run our regressions for only the twenty U.S. States with available Gallup religious datasets. Interestingly, we find that the results presented in Table 11 are consistent with our initial results. Our inferences still remain the same when religiosity was measured by a simple aggregate of the responses to the three Gallup questions on religion. Specifically, abnormal accruals is negatively and significantly $(\mathrm{p}<0.05)$ related to religiosity, both measures of real activities are positively and significantly $(\mathrm{p}<0.01)$ associated with religiosity and classification shifting is positively and significantly $(\mathrm{p}<0.01)$ associated with religiosity.

TABLE 11: Religiosity and Earnings Management in Twenty US States

\begin{tabular}{|c|c|c|c|c|}
\hline VARIABLE & ABNOR_ACC & RAELMGMT1 & REALMGMT2 & ABNOR_CORE \\
\hline \multirow[t]{2}{*}{ CONSTANT } & $0.368 * *$ & $0.157 * *$ & $0.131 * *$ & $0.160 * *$ \\
\hline & $-0.024 * *$ & $0.180 * * *$ & $0.089 * * *$ & $0.023 * *$ \\
\hline \multirow[t]{2}{*}{ REL } & $(-2.170)$ & $(2.750)$ & $(3.270)$ & $(2.890)$ \\
\hline & $-0.007 * *$ & $-0.050 * * *$ & $-0.033 * * *$ & $0.037 * *$ \\
\hline \multirow[t]{2}{*}{ SIZE } & $(-2.060)$ & $(-4.150)$ & $(-8.780)$ & $(1.920)$ \\
\hline & -0.004 & $-0.033 * *$ & $-0.033 * *$ & 0.007 \\
\hline \multirow[t]{2}{*}{ ANALYST_FOL } & $(-1.370)$ & $(-2.440)$ & $(-2.340)$ & $(1.510)$ \\
\hline & $-0.085 * * *$ & $-0.275^{* * *}$ & $-0.105^{* * *}$ & $-0.082 * * *$ \\
\hline \multirow[t]{2}{*}{ ROA } & $(-5.320)$ & $(-3.510)$ & $(-3.380)$ & $(-4.470)$ \\
\hline & $0.015^{* *}$ & 0.059 & 0.020 & $0.052 * * *$ \\
\hline \multirow[t]{2}{*}{$\mathrm{LEV}$} & $(2.170)$ & $(2.580)$ & $(0.120)$ & $(3.180)$ \\
\hline & -0.020 & $-0.082 *$ & $0.051 * *$ & 0.053 \\
\hline \multirow[t]{2}{*}{ BIG4 } & $(-1.460)$ & $(-1.730)$ & $(2.180)$ & $(0.590)$ \\
\hline & 0.003 & $0.025^{* * *}$ & $0.014 * *$ & $0.051 * * *$ \\
\hline \multirow[t]{2}{*}{ MBV } & $(1.150)$ & $(2.330)$ & $(2.240)$ & $(3.430)$ \\
\hline & $0.004 * *$ & $0.024 *$ & $0.072 * * *$ & $0.042 * * *$ \\
\hline \multirow[t]{2}{*}{ LOSS } & $(2.170)$ & $(1.730)$ & $(3.250)$ & $(5.120)$ \\
\hline & $0.010 * *$ & 0.003 & 0.002 & $0.005^{*}$ \\
\hline \multirow[t]{2}{*}{ OPERA_RISK } & $(2.380)$ & $(1.100)$ & $(1.420)$ & $(1.780)$ \\
\hline & 0.007 & 0.028 & $-0.036^{*}$ & $-0.120 *$ \\
\hline \multirow[t]{2}{*}{ BENCHMARK } & $(0.540)$ & $(1.020)$ & $(-1.790)$ & $(-1.700)$ \\
\hline & -0.001 & -0.002 & -0.007 & -0.002 \\
\hline \multirow[t]{2}{*}{ TENURE } & $(-0.360)$ & $(-0.060)$ & $(-0.520)$ & $(-0.540)$ \\
\hline & $0.017 * *$ & $-0.013^{*}$ & $0.017 * *$ & -0.003 \\
\hline \multirow[t]{2}{*}{ CHANGE_GDP } & $(2.040)$ & $(-1.760)$ & $(1.990)$ & $(-0.910)$ \\
\hline & $-0.092 *$ & $-0.394 * * *$ & $-0.169 *$ & $0.112 * * *$ \\
\hline \multirow[t]{2}{*}{ INVESTMENT } & $(-1.770)$ & $(-3.620)$ & $(-1.670)$ & $(5.600)$ \\
\hline & $0.012 * * *$ & $0.055^{*}$ & 0.023 & $0.031 * * *$ \\
\hline NOA & $(3.970)$ & $(1.880)$ & $(0.760)$ & $(4.160)$ \\
\hline $\begin{array}{l}\text { Demographic Cont. } \\
\text { Variables }\end{array}$ & Yes & Yes & Yes & Yes \\
\hline
\end{tabular}




$\begin{array}{lcccc}\text { Industry Fixed Effects } & \text { Yes } & \text { Yes } & \text { Yes } & \text { Yes } \\ \text { Observations } & 4445 & 3831 & 3831 & 4445 \\ \text { Adj. R-square (overall) } & 0.24 & 0.13 & 0.20 & 0.26\end{array}$

Notes: We use *,**, *** in a two tailed test to respectively indicate statistical significance at 10 percent, 5 percent and 1 percent levels. We estimate models 1, 2, 3 and 4 using fixed effects regression. Table 11 reports the association between religiosity and earnings management using a subsample of firms in the most and least religious U.S. states based on Gallup survey. T-statistics for all models are reported in parentheses below coefficient estimates. All other variables are defined above and in the Appendix A.

Overall, the results demonstrate that religious social norms minimises accruals-based earnings management but managers in highly religious environment have preference for realactivities and classification shifting earnings management because there is no GAAP violation, there is lack of external and internal monitoring and that both methods are deemed acceptable and appropriate.

\section{CONCLUSION}

Previous studies (Zalata and Roberts, 2015; Kim and Park, 2014; Donelson et al., 2013) on earnings management have shown that managers use different methods to manage reported income. Several studies also report that a firm's corporate governance mechanism mitigates earnings management practices. We build on prior studies (McGuire et al 2012; Dyreng et al. 2010) to establish the association between religiosity and classification shifting earnings management and the moderating effect of corporate governance variables and religiosity.

We contribute to the earnings management literature and report that religiosity is positively associated with classification shifting earnings management. We provide evidence that religious social norms of the firm's environment complement corporate governance mechanisms to curb accruals earnings management but real activities and classification shifting is pervasive and significant in an environment where religious social norms influence managerial behaviour and decisions. Furthermore, our findings show the importance of religious social norms in shaping shareholders value, therefore, the results are useful for regulators, external monitors, investors and shareholders to help create value for shareholders.

The article has several policy and practical implications. Firstly, the findings are consistent with social norm theory as social norms are reported to shape the behaviour and attitudes of managers in corporate decision making. This is important because religion is scarcely 
mentioned or discussed in secular organisations but an understanding of the role of religion in improving corporate financial reporting will shape policy decisions to create value for shareholders. Again, our findings have important implications for policy makers and regulators as they contribute to the debate on the choice between earnings management practices and corporate governance mechanism in an environment where religious social norms are predominant. The study also has implications for understanding factors that affect earnings management and the associated interaction between religiosity and corporate governance. The study highlights the need to monitor management behaviour and institute independent regulators to improve investor protection. 


\section{REFERENCES}

Abbott, L. J., Parker, S., Peters, G. F. and Raghunandan, K. (2003), An Empirical Investigation of Audit Fees, Non-audit Fees, and Audit Committees. Contemporary Accounting Research, Volume 20, Issue 2, pages 215-234.

Alissa, W., Bonsall, S.B., Koharki, K., Penn Jr. M.W., (2013). Firms' use of accounting discretion to influence their credit ratings, Journal of Accounting and Economics, volume 55, pp. 129-147.

Armstrong, C.S., Guay,W.R., and Weber, J.P., (2010a.) The role of information and financial reporting in corporate governance and debt contracting. Journal of Accounting and Economics, 50 (2/3), 179-234.

Ashbaugh-Skaife, H., Collins, D.W., Lafond, R. (2006). The effects of corporate governance on firms' credit ratings. Journal of Accounting and Economics 42 (2006) 203-243

Athanasakou, V.E., Strong, N.C. and Walker, M. (2009). "Earnings Management or Forecast Guidance to Meet Analyst Expectations?" Accounting and Business Research 39(1): 3-35.

Ayers, B. C., Ramalingegowda, S and Yeung, P. E. (2011). Hometown Advantage: The Effects of Monitoring Institution Location on Financial Reporting Discretion. Journal of Accounting \& Economics (JAE), Forthcoming

Badertscher, B.A. (2011) - Overvaluation and Its Effect on Management's Choice of Alternative Earnings Management Mechanisms," The Accounting Review, 86, September, 2011, 1491-1518.

Ball, R. and Shivakumar, L. (2008). "Earnings quality at initial public offerings." Journal of Accounting and Economics 45(2-3): 324-349.

Baker, T. A., Collins, D .L. and Reitenga, A. L. (2009). Incentives and opportunities to manage earnings around option grants. Contemporary Accounting Research 26 (3): 649-72.

Barnett, M. L., Jermier, J.M. and Lafferty, B.A. (2006). Corporate reputation: The definitional landscape. Corporate Reputation Review 9 (1): 26-38.

Barnea, A., Ronen, J. and Sadan, S. (1975) - The Implementation of Accounting Objectives: An Application to Extraordinary Items, The Accounting Review, Vol. 50, No. 1, pp. 58-68

Barro, R. J., and R. M. McCleary (2003). Religion and economic growth across countries. American Sociological Review 68 (5): 760-781.

Barton, J. (2005). Who cares about auditor reputation? Contemporary Accounting Research 22 (3): 549-86. 
Behn, B. K., Gotti, G., Herrmann, D. and Kang, T. (2013). Classification Shifting in an International Setting: Investor Protection and Financial Analysts Monitoring. Journal of International Accounting Research. Vol. 12, No. 2, pp. 27-50.

Boone, J. P., Khurana, I. K., and Raman, K. K. (2012). Audit market concentration and auditor tolerance for earnings management, ? Contemporary Accounting Research, Vol. 29, No. 4, 01.12.2012, p. 1171-1203..

Brochet, F., Miller, G.S. and Srinivasan, S. (2013). Do Analysts Follow Managers Who Switch Companies? An Analysis of Relationships in the Capital Markets-The Accounting Review 89 (2), 451-482.

Bruns, W., and K. Merchant (1990). The dangerous morality of managing earnings. Management Accounting 72 (2): 22-25.

Cadman, B. and Sunder, J. (2014) Investor Horizon and CEO Horizon Incentives. The Accounting Review 89:4, 1299-1328

Callen, J. L., Morel, M. and Richardson, G. (2011). Do culture and religion mitigate earnings management? Evidence from a cross-country analysis. International Journal of Disclosure and Governance 8 (2): 103-121.

Cao, Y., Myers, L.A. and Omer, T.C. (2012). Does company reputation matter for financial reporting quality. Evidence from restatements. Contemporary Accounting Research, Vol. 29 No. 3, 956-990.

Chau, L. and Gary. M (2010). Outside directors and CEO turnover, Journal of Financial Economics 20, 431-460. The Journal of Finance, Volume 52, Issue 2, pages 737-783, June 1997

Cialdini, R. B., and N. J. Goldstein (2004). Social influence: Compliance and conformity. Annual Review of Psychology 55 (1): 591-621.

Cohen, D.A. and Zarowin, P., (2010). "Accrual-based and real earnings management activities around seasoned equity offerings." Journal of Accounting and Economics 50(1): 219.

Coles, J. L, Daniel, N. D, Naveen, L. (2008). Boards: does one size fit all? Journal of Financial Economics 87(2): 329-356.

Conroy S. J., and T. L. N. Emerson (2004). Business ethics and religion: Religiosity as a predictor of ethical awareness among students. Journal of Business Ethics 50 (4): 383-396.

Cullen and Christopher, (2002). Culture and corporate governance, Journal of Business Ethics 50 (4): 383-396. 
Daniel, N.D., Denis, D.J., and Naveen, L., (2008). Do firms manage earnings to meet dividend thresholds? Journal of Accounting and Economics, 45 (1), 2-26.

Dechow, P. M., Hutton, A. P., Kim, J. H. and Sloan, R. (2012). Detecting Earnings Management: A New Approach. Journal of Accounting Research. Volume 50, Issue 2, pages 275-334, May 2012.

Dechow, P., Sloan, R. and Sweeney, A. (1996). "Causes and consequences of earnings manipulation: An analysis of firms subject to enforcement actions by the SEC." Contemporary Accounting Research 13(1): 1-36

Donelson, D.C., Mcinnis J.M., Mergenthaler, R.D., (2013). Discontinuities and Earnings Management: Evidence from Restatements Related to Securities Litigation, Contemporary Accounting Research, volume 30, number 1, pp. 242-268

Doyle J.T., Jennings J., Soliman M.T., (2013). Do Managers Define Non-GAAP Earnings to Meet or Beat Analyst Forecasts?, Journal of Accounting and Economics, volume 56, pp. 40-

56

Dyreng, S. D., W. J. Mayew, and C. D. Williams (2010). Religious Social Norms and Corporate Financial Reporting. Working paper, Duke University and The University of Michigan.

Elster, J. (1989) Social Norms and Economic Theory. The Journal of Economic Perspectives Vol. 3, No. 4 (Autumn, 1989), pp. 99-117

Fan, Y., Barua, A., Cready, W.M. and Thomas, W. (2010). "Managing Earnings Using Classification Shifting: Evidence from Quarterly Special Items." The Accounting Review 85(4): 1303-1323.

Francis, J. R., and M. D. Yu. 2009. The effect of Big 4 office size on audit quality. The Accounting Review 84 (5): 1521-52.

Francis, J. R., Huang, A. H. Rajgopal, S. and A. Y. Zang, A. Y. (2008b). CEO reputation and earnings quality. Contemporary Accounting Research 25 (1): 109-47.

Gao P. (2013). A measurement approach to conservatism and earnings management, Journal of Accounting and Economics, volume 55, pp. 251-268

Gerakos J., Kovrijnykh A., (2013). Performance Shocks and Misreporting, Journal of Accounting and Economics, volume 56, pp. 57-72

Gonzalez, J. S. and Garcia-meca, E. (2014). Does Corporate Governance Influence Earnings Management in Latin American Markets?. Journal of Business Ethics, vol. 121, 419-440

Graham, J. R., Harvey, C.R. and Rajgopal, S. (2005). "The Economics Implications of Corporate Financial Reporting." Journal of Accounting and Economics 40(1/3): 3-73. 
Grullon, G., G. Kanatas, and J. Weston (2010). Religion and Corporate (Mis) Behavior. Working paper, Rice University.

Guiso, L., P. Sapienza, and L. Zingales (2006). Does culture affect economic outcomes? Journal of Economic Perspectives 20 (2): 23-48.

Guiso, L., Sapienza, P., Zingales, L., (2003) People's opium? Religion and economic attitudes, Journal of Monetary Economics, 50(1): 225-282.

Gunny, K. (2010). The relation between earnings management using real activities manipulation and future performance: Evidence from meeting earnings benchmarks. Contemporary Accounting Research 27 (3): 855-888.

Harris, M., and Raviv, A. (2008). A theory of Board Control and size. The Review of Financial Studies, 21.4: 1797-1832.

Haw, M., Ho, S.M., and Li, A.Y., (2011). Corporate Governance and Earnings Management by Classification Shifting - Contemporary Accounting Research. Vol 28 pp. 517-553

Hilary, G., and K. W. Hui. (2009). Does religion matter in corporate decision making in America? Journal of Financial Economics 93 (3): 455-473.

Horton J., Serafeim, G., Serafeim I., (2013). Does Mandatory IFRS Adoption Improve the Information Environment?, Contemporary Accounting Research, volume 30, number 1, pp. $388-42$

Hossain, M., Mitra, S., Rezaee, Z. and Sarath, B (2011). Corporate Governance and Earnings Management in the pre and post - Sarbanes-Oxley Act Regimes Evidence from Implicated Option Backdating Firms. Journal of Accounting, Auditing \& Finance. 26: 279-315. .

Iannaccone, L. (1998). Introduction to the economics of religion. Journal of Economic Literature 36 (3): 1465-1496.

Jo, H._and_Harjoto, M. A. (2012) The Causal Effect of Corporate Governance on Corporate Social Responsibility. Journal of Business Ethics 106 (1):53-72.

Jo, H. and_Harjoto, M. A. (2011). Corporate Governance and firm value: The Impact of Corporate Social Responsibility. Journal of Business Ethics 103 (3):351-383

Keister, L. A. (2003). Religion and wealth: The role of religious affiliation and participation in early adult asset accumulation. Social Forces 82, 175-207.

Kennedy, E. J., and L. Lawton (1998). Religiousness and business ethics. Journal of Business Ethics 17 (2): 163-175.

Kim, Y and Park, M.S. (2014). Real Activities Manipulation and Auditors' Client-Retention Decisions, The Accounting Review, January 2014, Vol. 89, No. 1, pp. 367-401 
Kim, K., Mauldin, E. and Patro, S. (2014) .Outside directors and board advising and monitoring performance. Journal of Accounting and Economics, Volume 57, Issues 2-3, April-May 2014, Pages 110-131

Klein, A. (2002). Audit committee, board of director characteristics, and earnings management. Journal of Accounting and Economics 33 (3): 375-400.

Kothari, S.P., Leone, A.J. and Wasley, C.E., (2005). Performance Matched Discretionary Accruals Measures. Journal of Accounting and Economics 39, 163-197.

Lehrer, E. L. (2004). Religion as a determinant of economic and demographic behaviour in the United States. Population and Development Review 30 (4): 707-726.

Levitt, A. (1998), 'The Numbers Game', New York University Center for Law and Business (http://www.sec.gov/news/speech/speecharchive/1998/spch220.txt).

LiLin, J.W. and Hwang, M. I. (2010). Audit quality, corporate governance and earnings management: a meta analysis. International Journal of Auditing, 14:57-77.

Longenecker, J. G., J. A. McKinney, and C. W. Moore (2004). Religious intensity, evangelical Christianity, and business ethics: An empirical study. Journal of Business Ethics 55 (4): 373-386.

Loughran, T. and Schultz, P. (2005). Liquidity: Urban versus rural firms. Journal of Financial Economics, Volume 78, Issue 2, November 2005, Pages 341-374.

McVay, S. (2006). "Earnings Management using Classification shifting: an examination of core earnings and special items." The Accounting Review 81(3): 501-531.

McGuire, T.S., Omer, T.C., Sharp, N.Y (2012) "The Impact of Religion on Financial Reporting Irregularities" The Accounting Review, Volume 87, Issue 2 (March 2012)

Mersland, R., D'Espallier, B., \& Supphellen, M. (2012). The effects of religion on development efforts: Evidence from the Microfinance industry and research agenda. World Development (2012), http://dx.doi.org/10.1016/j.worldev.2012.05.030.

Meyer, J.W. and Brian Rowan, B. (1977). Institutionalized Organizations: Formal Structure as Myth and Ceremony, American Journal of Sociology, Vol. 83, No. 2 (Sep., 1977), pp. 340363

Nelson, M., Elliot, J. and Tarpley, R. (2002). Evidence from auditors' about managers' and auditors' earnings management decisions. The Accounting Review 77 (supplement): 175-202.

Omer, T. C., Sharp, N.Y. and Wang, D. (2010). Do Local Religious Norms Affect Auditors' Going Concern Decisions? Working paper, Texas A\&M University. 
Parboteeah, K. P., Hoegl, M and Cullen, J.B. (2008). Ethics and religion: An empirical test of a multidimensional model. Journal of Business Ethics 80 (2): 387-398.

Peasnell, K. V., Pope, P.F. \& Young, S. (2005). Board monitoring and earnings management: Do outside directors' influence abnormal accruals? Journal of Business Finance \& Accounting 32: 1311-1346.

Renneboog, L. and Spaenjers, C. (2011). Religion, Economic Attitudes, and Household Finance (January 27, 2011). Oxford Economic Papers, Vol. 64, No. 1, 2012

Roychowdhury, S. (2006). "Earning Management through real activities manipulation." Journal of Accounting and Economics 42(3): 335-370

Scott, W. R. (1997). Financial Accounting Theory, pp. 302-307

Scott, W. R. (1987). The Adolescence of Institutional Theory, Administrative Science Quarterly, Vol. 32, No. 4 (Dec., 1987), pp. 493-511

Shu, T., Sulaeman, J. and Yeung, P.E. (2012), 'Local Religious Beliefs and Mutual Fund Risk Taking Behaviours', Management Science, Articles in Advance, pp. 1-18 (http://dx.doi.org/10.1287/mnsc.1120.1525).

Srinivasan, S. (2013). Consequences of financial reporting failure for outside directors: Evidence from accounting restatements and audit committee members. Accounting Review $88: 5,1683-1714$.

Sunder, S. (2005). Minding our manners: Accounting as social norms, The British Accounting Review, Volume 37, Issue 4, December 2005, Pages 367-387

Sunstein, C. R. (1996). Social norms and social rules. Columbia Law Review 96 (4): 903968.

Tayler, W. and R. Bloomfield (2010), 'Norms, Conformity and Controls', Journal of Accounting Research, Vol. 49, pp. 753-90.

Ter Haar, G., \& Ellis, S. (2006). The role of religion in development: Towards a new relationship between the European Union and Africa. The European Journal of Development Research, 18, 351-367.

Terpstra, D. E., Rozell, E.J. and Robinson, R.K. (1993). The influence of personality and demographic variables on ethical decisions related to insider trading. The Journal of Psychology 127 (4): 375-389.

Veprauskaite, E. and Adams, M. (2013). Do powerful chief executives influence the financial performance of UK firms?.The British Accounting Review, Volume 45, Issue 3, September 2013, Pages 229-241 
Vitell, S. J. (2009) The role of religiosity in business and consumer ethics: A review of the literature. Journal of Business Ethics 90: 155 - 167.

Weaver, G. R., and B. R. Agle (2002). Religiosity and ethical behaviour in organizations: A symbolic interactionist perspective. Academy of Management Review 27 (1): 77-97.

Welch, M. R., Tittle, C. R. and Petee, T. (1991). Religion and deviance among adult Catholics: A test of the "moral communities" hypothesis. Journal for the Scientific Study of Religion 30 (2): 159-172.

Wongsunwai, W., (2013). The Effect of External Monitoring on Accrual-Based and Real Earnings Management: Evidence from Venture- Backed Initial Public Offerings,

Contemporary Accounting Research, volume 30, number 1, pp. 296-324

Xie, B., Davidson, W.N. and DaDalt, P.J. (2003). Earnings management and corporate governance: the role of board and the audit committee. Journal of Corporate Finance, 9: 295-316.

Zalata, A and Robert, C (2015). Internal Corporate Governance and Classification Shifting Practices - An Analysis of U.K. Corporate Behaviour. Journal of Accounting, Auditing and Finance.

Zang, A.Y. (2012). "Evidence on the Trade-Off between Real Activities Manipulation and Accrual-Based Earnings Management." The Accounting Review 87(2): 675-703.

Zhang, J., (2008). The contracting benefits of accounting conservatism to lenders and borrowers. Journal of Accounting and Economics, 45 (1), 27-54. 


\section{APPENDICES}

Appendix A: The following table shows the measurement of variables in the study:

\begin{tabular}{|c|c|c|}
\hline Variables & Proxy & Definition \\
\hline Religiosity & $R E L$ & $\begin{array}{l}\text { Strength of religiosity for each U.S. county measured by } \\
\text { Association of Statisticians of American Religious Bodies } \\
\text { (ASARB) surveys. The results of these surveys are published } \\
\text { on the website of Association of Religion Data Archive } \\
\text { (ARDA). The average of each county religiosity score is } \\
\text { weighted by the county's population. }\end{array}$ \\
\hline $\begin{array}{l}\text { Abnormal } \\
\text { Accruals }\end{array}$ & $\begin{array}{c}\text { ABNOR_ACCRUAL } \\
\text { S }\end{array}$ & $\begin{array}{l}\text { Measure of abnormal accruals or residuals using the } \\
\text { Modified-Jones model in equation 1. (McGuire et al. 2012; } \\
\text { Defond and Jiambalvo, 1994; Dechow et al. 1995) See below. }\end{array}$ \\
\hline $\begin{array}{l}\text { Discretionary } \\
\text { Expenses }\end{array}$ & D_EXP & $\begin{array}{l}\text { Measured as the aggregate of advertising expenses, R\& D } \\
\text { expenses, SG \& A expenses scaled by lagged total assets }\end{array}$ \\
\hline $\begin{array}{l}\text { Abnormal } \\
\text { Discretionary } \\
\text { Expenses }\end{array}$ & ABNOR_DEXP & $\begin{array}{l}\text { Estimated after regressing discretionary expenses on the } \\
\text { inverse of lagged total assets and lagged sales scaled by } \\
\text { lagged total assets. The figure for }\left(A B N O R \_D E X P\right) \text { is } \\
\text { multiplied by negative one }(-1) \text {, consequently, a higher } \\
\left(A B N O R \_D E X P\right) \text { figure represents higher real earnings } \\
\text { management. }\end{array}$ \\
\hline $\begin{array}{l}\text { Cash flow from } \\
\text { operation }\end{array}$ & CASFO & $\begin{array}{l}\text { Is the cash flow from operational activities scaled lagged total } \\
\text { assets }\end{array}$ \\
\hline $\begin{array}{l}\text { Abnormal Cash } \\
\text { flow }\end{array}$ & ABNOR_CASH & $\begin{array}{l}\text { Estimated by regressing CASFO scaled by lagged total assets } \\
\text { on the inverse of lagged total assets, sales scaled by lagged } \\
\text { total assets, change in sales scaled by lagged total assets. The } \\
\text { figure for ( } A B N O R_{\text {_ CASH) is multiplied by negative one (- }} \\
\text { 1), consequently, a higher ( } A B N O R_{-} \text {CASH) figure represents } \\
\text { higher real earnings management. }\end{array}$ \\
\hline $\begin{array}{l}\text { Production } \\
\text { Costs }\end{array}$ & PCOST & $\begin{array}{l}\text { Measured as the aggregate of cost of sales and change in } \\
\text { inventory during the year scaled by lagged total assets. }\end{array}$ \\
\hline $\begin{array}{l}\text { Abnormal } \\
\text { Production } \\
\text { Costs }\end{array}$ & ABNOR_PCOST & $\begin{array}{l}\text { Residuals estimated by regressing PCOST on the inverse of } \\
\text { lagged total assets, sales scaled by lagged total assets, change } \\
\text { in sales scaled by lagged total assets. The figure for } \\
\left(A B N O R \_P C O S T\right) \text { is multiplied by negative one }(-1) \text {, } \\
\text { consequently, a higher (ABNOR_PCOST) figure represents } \\
\text { higher real earnings management. }\end{array}$ \\
\hline $\begin{array}{l}\text { Real Earnings } \\
\text { Activities } 1\end{array}$ & REALMGMT1 & $\begin{array}{l}\text { Calculated as the aggregate of abnormal discretionary } \\
\text { expenditures }\left(A B N O R \_D E X P\right) \text { and abnormal production costs } \\
\left(A B N O R \_P C O S T\right) \text {. The higher the value, the higher the levels } \\
\text { of real earnings management }\end{array}$ \\
\hline $\begin{array}{l}\text { Real Earnings } \\
\text { Activities } 2\end{array}$ & REALMGMT2 & $\begin{array}{l}\text { Calculated as the aggregate of abnormal discretionary } \\
\text { expenditure }\left(A B N O R \_D E X P\right) \text { and abnormal cash flows } \\
\left(A B N O R \_C A S H\right) \text {. The higher the value, the higher the level } \\
\text { of real earnings management }\end{array}$ \\
\hline Total Assets & TA & Measured as total Non-current assets plus total current assets \\
\hline Size of the Firm & SIZE & The natural log of total assets/Consumer Price Index \\
\hline $\begin{array}{l}\text { Analyst } \\
\text { Following }\end{array}$ & ANALYST_FOL & $\begin{array}{l}\text { Number of financial analysts following the firm in the } \\
\text { I/B/E/S summary file }\end{array}$ \\
\hline $\begin{array}{l}\text { Return on } \\
\text { Assets }\end{array}$ & ROA & $\begin{array}{l}\text { Measured as net income before extraordinary items divided } \\
\text { by average total assets }\end{array}$ \\
\hline Leverage & LEV & $\begin{array}{l}\text { Financial leverage, measured as total debts scaled by total } \\
\text { equity }\end{array}$ \\
\hline Presence of Big & BIG4 & firm was audited by big 4 , otherwise zero. \\
\hline
\end{tabular}




\begin{tabular}{|c|c|c|}
\hline 4 Auditors & & \\
\hline $\begin{array}{l}\text { Market to Book } \\
\text { Value }\end{array}$ & MBV & Measured as total assets divided by market capitalization \\
\hline Reported Loss & LOSS & $\begin{array}{l}\text { An indicator variable that equals } 1 \text { if income before } \\
\text { extraordinary items was negative in the current or previous } \\
\text { two fiscal years, and } 0 \text { otherwise; }\end{array}$ \\
\hline $\begin{array}{l}\text { Operational } \\
\text { Risk }\end{array}$ & OPERA_RISK & $\begin{array}{l}\text { Estimated as five year rolling standard deviation of operating } \\
\text { cash flows estimated from both current and previous four } \\
\text { years }\end{array}$ \\
\hline $\begin{array}{l}\text { Firm's located } \\
\text { in rural areas }\end{array}$ & RURAL & $\begin{array}{l}\text { Indicator variable that equals } 1 \text { if the firm is headquartered } \\
\text { outside the } 490 \text { largest counties in the sample, and } 0 \\
\text { otherwise }\end{array}$ \\
\hline Benchmark & BENCHMARK & $\begin{array}{l}\text { The indicator value is } 1 \text { if (a) net income scaled by total } \\
\text { assets is more than or equal to } 0 \text { and less than } 0.01 \text {. } \\
\text { Alternatively, if the change in net income scaled by total } \\
\text { assets from previous year to current year is greater than or } \\
\text { equal to } 0 \text { and less than } 0.01 \text {, and } 0 \text { otherwise; }\end{array}$ \\
\hline Auditor Tenure & TENURE & $\begin{array}{l}\text { Natural log of the number of years the auditor has been with } \\
\text { the firm }\end{array}$ \\
\hline Change in GDP & CHANGE_GDP & Annual percentage change in GDP \\
\hline $\begin{array}{l}\text { Firm Level of } \\
\text { Investment }\end{array}$ & INVESTMENT & $\begin{array}{l}\text { Percentage of capital expenditure at the beginning of the year } \\
\text { (t) to total net property, plant and equipment at the end of the } \\
\text { year }(t)\end{array}$ \\
\hline $\begin{array}{l}\text { Net Operating } \\
\text { Assets }\end{array}$ & NOA & $\begin{array}{l}\text { Defined as the sum of shareholders' equity less cash and } \\
\text { marketable securities plus total debt at the beginning of the } \\
\text { year, scaled by total assets at the beginning of the year }\end{array}$ \\
\hline Population & POPN & $\begin{array}{l}\text { Natural log of the estimate of the population for each US } \\
\text { State in millions. }\end{array}$ \\
\hline Income & INCOME & $\begin{array}{l}\text { Household income for each US State in ten thousands (\$) } \\
\text { estimated by Census Bureau. }\end{array}$ \\
\hline Education & EDU & $\begin{array}{l}\text { A measure of adult population in each US State with college } \\
\text { education, estimated by Gallup interviews. }\end{array}$ \\
\hline $\begin{array}{l}\text { Age of } \\
\text { respondents }\end{array}$ & AGE & $\begin{array}{l}\text { Average age of residents in each US State, based on the } \\
\text { responses from Gallup interviews. }\end{array}$ \\
\hline Minority & MINORITY & $\begin{array}{l}\text { Percentage of racial minorities in each US State, from } \\
\text { responses to the Gallup interviews. }\end{array}$ \\
\hline Political & POLITICAL & $\begin{array}{l}\text { Percentage of the adult population in each US State who is } \\
\text { affiliated with the Republican party, from Gallup interview } \\
\text { response. }\end{array}$ \\
\hline CEO-Tenure & CEO_TEN & $\begin{array}{l}\text { Measured as the number of years a CEO has held the position } \\
\text { as CEO in the organisation }\end{array}$ \\
\hline $\begin{array}{l}\text { Audit } \\
\text { Committee } \\
\text { Presence }\end{array}$ & AUCOM & $\begin{array}{l}\text { A dummy variable coded as } 1 \text { if the company has an audit } \\
\text { committee, otherwise zero. }\end{array}$ \\
\hline $\begin{array}{l}\text { Independent } \\
\text { Board }\end{array}$ & BODIND & $\begin{array}{l}\text { Calculated as the number of independent directors divided by } \\
\text { the total number of directors on the board. Defined as non- } \\
\text { executive directors holding less than } 5 \% \text { of the voting } \\
\text { securities and having no direct or indirect interest or } \\
\text { relationship that could reasonably influence their objective } \\
\text { judgment and decision making }\end{array}$ \\
\hline
\end{tabular}




\begin{tabular}{|c|c|c|}
\hline Board Size & BODSIZE & Total number of directors on the board \\
\hline $\begin{array}{l}\text { Religiosity } \\
\text { interacts Board } \\
\text { size }\end{array}$ & RELBODSIZE & Religiosity multiplied by Board Size \\
\hline $\begin{array}{l}\text { Religiosity } \\
\text { interacts Board } \\
\text { independence }\end{array}$ & RELBODIND & Religiosity multiplied by Board independence \\
\hline $\begin{array}{l}\text { Religiosity } \\
\text { interacts Audit } \\
\text { Committee }\end{array}$ & RELAUCOM & Religiosity multiplied by Audit committee \\
\hline $\begin{array}{l}\text { Religiosity } \\
\text { interacts CEO } \\
\text { tenure }\end{array}$ & RELCEOTEN & Religiosity multiplied by CEO turnover \\
\hline $\begin{array}{l}\text { Normal Core } \\
\text { Earnings }\end{array}$ & NOR_CE & $\begin{array}{l}\text { This is the core earnings that is actually expected to occur in } \\
\text { the normal course of business activity devoid of classification } \\
\text { shifting. The study follows McVay (2006) expectation model } \\
\text { in equation } 6 \text {. }\end{array}$ \\
\hline $\begin{array}{l}\text { Reported Core } \\
\text { Earnings }\end{array}$ & REP_CE & $\begin{array}{l}\text { Estimated as sales - cost of goods sold - selling, general and } \\
\text { administration expenses. Depreciation and Amortization are } \\
\text { excluded from Cost of Sales, Selling, General and } \\
\text { Administrative Expenses. }\end{array}$ \\
\hline $\begin{array}{l}\text { Unexpected } \\
\text { Core Earnings }\end{array}$ & UNEXP_CE & $\begin{array}{l}\text { Is the difference between reported and normal or expected } \\
\text { core earnings (McVay, 2006). }\end{array}$ \\
\hline Asset Turnover & ATO & $\begin{array}{l}\text { Sales scaled by average net operating assets. Where net } \\
\text { operating assets is the difference between operating assets } \\
\text { and operating liabilities. Operating assets = Total assets - } \\
\text { Cash and Cash equivalent. Operating Liabilities = Total } \\
\text { assets - Total debt - Book value of common equity - } \\
\text { Preferred equity - Minority interests. }\end{array}$ \\
\hline Total Accruals & TAC & $\begin{array}{l}\text { Difference between earnings before extraordinary items and } \\
\text { discontinued operations and the cash flow from operational } \\
\text { activities scaled by lagged total assets }\end{array}$ \\
\hline $\begin{array}{l}\text { Operating } \\
\text { Accrual }\end{array}$ & ACCRUALS & $\begin{array}{l}\text { Operating Accrual }=(\text { Net income before extraordinary items } \\
- \text { cash flow from operation }) / \text { Sales. }\end{array}$ \\
\hline $\begin{array}{l}\text { Working } \\
\text { Capital } \\
\text { Accruals } \\
\end{array}$ & WC_ACCRUALS & $\begin{array}{l}\text { Measured as earnings before extraordinary items plus } \\
\text { depreciation and amortisation minus cash flow from } \\
\text { operational activities. }\end{array}$ \\
\hline $\begin{array}{l}\text { Percent change } \\
\text { in sales }\end{array}$ & $\Delta$ Sales & $\left(\right.$ Sales $_{t}-$ Sales $\left._{t-1}\right) /$ Sales $_{t}$ \\
\hline $\begin{array}{l}\text { \% change in } \\
\text { Sales }\end{array}$ & NEG_ $\Delta$ Sales & where $\triangle$ SALES is less than 0 , otherwise zero \\
\hline
\end{tabular}




\section{Appendix B: Sample Selection Procedures and Derivation}

Description (Sample Period: 2004-2013)

\begin{tabular}{|l|c|}
\hline Initial Sample: Firm year observations with financial data & $\mathbf{7 8 , 0 2 6}$ \\
\hline Exclude: Financial services Companies (SIC Codes 60-69) & $(20,251)$ \\
\hline Exclude: Firms with missing financial information & $(10,883)$ \\
\hline $\begin{array}{l}\text { Exclude: Observations with less than 8 firms in each SIC/year } \\
\text { combination }\end{array}$ & $(29,117)$ \\
\hline Exclude: Firms with revenue less than \$500,000 & $\mathbf{1 1 , 1 0 5}$ \\
\hline Final usable sample & \\
\hline Number of unique firms $=\mathbf{1 , 6 1 6}$ firms & \\
\hline
\end{tabular}


Appendix C: Classification by Year and Industry

\begin{tabular}{|c|c|c|c|c|c|c|c|c|c|c|c|c|}
\hline SIC & Industry & 2004 & 2005 & 2006 & 2007 & 2008 & 2009 & 2010 & 2011 & 2012 & 2013 & Total \\
\hline 10 & Metal Mining & 8 & 11 & 13 & 13 & 13 & 15 & 17 & 15 & 14 & 8 & 127 \\
\hline 13 & Oil \& Gas & 66 & 68 & 71 & 72 & 70 & 68 & 70 & 67 & 71 & 8 & 631 \\
\hline 20 & $\begin{array}{l}\text { Food And Kindred } \\
\text { Products }\end{array}$ & 23 & 25 & 29 & 33 & 35 & 36 & 39 & 42 & 45 & 46 & 353 \\
\hline 22 & $\begin{array}{lll}\text { Textile } & \& & \text { Printing } \\
\text { Products } & & \\
\end{array}$ & 31 & 33 & 37 & 41 & 43 & 44 & 47 & 51 & 54 & 56 & 437 \\
\hline 27 & Printing And Publishing & 18 & 21 & 19 & 19 & 19 & 17 & 15 & 14 & 14 & 9 & 165 \\
\hline 28 & $\begin{array}{lll}\begin{array}{l}\text { Chemicals } \\
\text { Products }\end{array} & \& & \text { Allied } \\
\end{array}$ & 103 & 145 & 148 & 137 & 136 & 128 & 126 & 124 & 112 & 14 & 1,173 \\
\hline 34 & Primary Metal Products & 80 & 96 & 93 & 84 & 81 & 79 & 77 & 75 & 76 & 10 & 751 \\
\hline 35 & $\begin{array}{l}\text { Industrial Machinery \& } \\
\text { Eqmt. }\end{array}$ & 85 & 113 & 102 & 103 & 100 & 97 & 97 & 98 & 95 & 19 & 909 \\
\hline 36 & Electronic Equipment & 119 & 180 & 179 & 179 & 168 & 160 & 157 & 146 & 139 & 28 & 1,455 \\
\hline 37 & Transportation Equipment & 29 & 40 & 43 & 46 & 46 & 45 & 45 & 44 & 45 & 10 & 393 \\
\hline 38 & $\begin{array}{l}\text { Instruments \& } \begin{array}{l}\text { Related } \\
\text { Prod. }\end{array} \\
\end{array}$ & 135 & 195 & 196 & 183 & 173 & 160 & 153 & 145 & 132 & 37 & 1,509 \\
\hline 48 & Communications & 39 & 36 & 39 & 35 & 32 & 31 & 29 & 27 & 25 & 10 & 303 \\
\hline 49 & $\begin{array}{l}\text { Elect, Gas \& Sanitary } \\
\text { Serv. }\end{array}$ & 11 & 21 & 21 & 21 & 19 & 20 & 19 & 15 & 15 & 11 & 173 \\
\hline 50 & $\begin{array}{lll}\text { Wholesale } & \text { Trade } & \text { - } \\
\text { Durables } & & \\
\end{array}$ & 123 & 164 & 151 & 141 & 135 & 134 & 131 & 125 & 120 & 18 & 1,242 \\
\hline 73 & Business Services & 96 & 130 & 134 & 116 & 104 & 98 & 92 & 83 & 87 & 13 & 953 \\
\hline 79 & Amusement \& Recreation & 8 & 12 & 12 & 10 & 10 & 10 & 10 & 12 & 12 & 11 & 107 \\
\hline 80 & Health Services & 17 & 23 & 25 & 24 & 24 & 24 & 24 & 20 & 16 & 14 & 211 \\
\hline 87 & Eng. \& Mgmt. Services & 24 & 29 & 30 & 26 & 23 & 20 & 19 & 15 & 15 & 12 & 213 \\
\hline & Total & 1015 & 1342 & 1342 & 1283 & 1231 & 1186 & 1167 & 1118 & 1087 & 334 & 11,105 \\
\hline
\end{tabular}


